\title{
乘法の成立過 程
}

東亲帝國大學心理學研労室

松 本 彦 三 郎

\section{I. 問 題}

乘法は通俗には加法の簡便法で兆ると定義される。此定義は加法と乘法とを同一の本 面に於て見比べた限りに於ては正當であるが，然しそれでは加法は第一段階の算法であ り乘法は第二段階の算法であるといら段階の相違を舆視し數學の通念に背反する。加法 を理解し然し乘法に就ては未だ淺い理解しか有なない初學者に於ては, 問題の解決は精 精加法にて試みられ, 乘法的解決は煩頊で困蜼でさへむつて, 加法と乘法とを同等の高 さに置かうとすることはここでも不合理である。元來, 簡便といふ語は Praxis に關し ての用語で, 多くの場合に慣熟といふ語と同義であり得る。こ〉では簡便の語は渾算の 形式上の手續に關して言はれてるるが, 斯る手續上の簡便は直ぐ樣, 心理的簡便索意味 しない。この故に上の定義は徹底を缺く所があるが，然し全然無意義とは言ひ䧼い。何 に由つて乘法は加法よりも簡便なのであるか, といふ問題の提起を動機づけてくれるの は上揭の定義だからである。

乘法は特殊なる加法であると定義される。加法は, 加法である限り, 如何に特殊なる ものであつても乘法から區別される。既に見た樣に乘法と加法とに段階の相違を無視す ることは不合理であるからだ。然しこの定戔は, 乘法は特殊なる加法問題に摙月される もの代といふことを言つてるると解する時, 少しく容認される。乘法は加法のすべての 問題に適用されるのではなく，一定の條件を充足する特殊なる加法問題に適用さ如る。 即ら乘法は $a+b+a^{\prime}+c+d \ldots$ の如き問題にではなく, $a+a+a+a \ldots$ の如き特殊なる構造 を有する問題に適用されるのである。さりながら, 其故に上の定義を全的に認めること は出來ない、實際の問題解決に當つて, 加法と乘法と何れの算法起選ぶかは一に解決當 事者の任意であり, 課題者の例から乘法的解決を期待しても, 解答者にして乘法の理解 にこしいならば, その期待は裏切られる。此故に此定義は同情を以て解釋しても, 向ほ 不徽底の餘地を殘してるるが，乘法の適用せらるべき問題が特殊なる構浩を有すること を指摘してるる所は注目せねばならない。

乘法に關する第三の定義は「數 $a$ に $m$ を乘ずるとはどの數も $a$ である樣な斯る被加數 $m$ 個の總和をつくることである」と云ひ, 而してそれは次の如き乘法の說明式を敍述し 
たものとせられてるる。
(1) (2) (3) (4)
$a+a+a+a+\cdots \cdots+a+a=a \cdot m$

然しかの述文は此式に一敨しない。述文に忠實に立式を試みるならば

$a . m=\overbrace{a+a+a+a+\cdots \cdots+a}^{m \text { r }}$

となり, 之と上式とは a.mの位置が等號の石邊と左邊とに相違してるるのみならず, こ れと等置せられてるる他の式の位㨁及び構造をも異にしてしるる。しかのみならず，

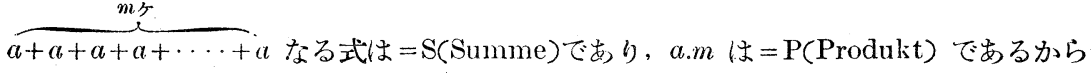

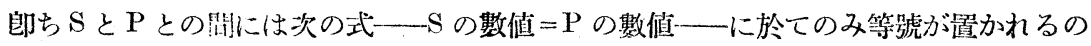
であつて, 上記の第二式は成立不可能なるものとなり, 定菚の述文も不合理を含むこと。 になる。

乘法の特色一゙けが問題を解決する乎續の上から, 或は間題の構造の特殊性の上から, 或はこの三つの立場を包括する第三の立場から試みられても, 乘法を乘法そのものとし て見ようとしないで加法への還元を以て足れりとする限り，乘法の特色は解明されない。

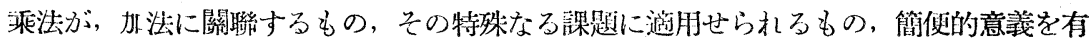
するものでむることは解つても, 乘法の累進的算法としての第二段階性は不問に附せら れ，依然として不明のままである。この點に關して，第三の定義をその述文とする彼の 式述は，その述交から切踓してそれ自身として考察する時は，耕法の特色を言明してる る樣に見える。式の有邊は明白に乘泆の結果であり, その左邊はプラス記號を以て結合 さ机てるるが，之は＝S とせらるべき式以上:のものを含んでるる。郎ち, 各項の上に附 記せられた指標 (1)，(2)，(3)，(m) は加法の式には胃られない特殊のものである。これ 乘法の特徵ではないだららか。か?考へ來る時に, 然らばこの指標は如何なる條件の下 に起源し，如何なる條件のもとに墢展するものであるか。一體この指標は何でもり，何 を意義づけ，心理的には何を意味するものであらうか。

\section{II. 實驗の諸條件}

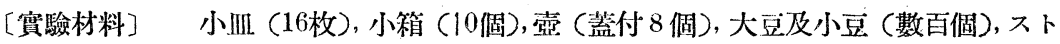

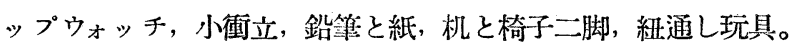

〔實驗場及びその配借〕東京市淺草區山谷堀小學校地理準備室。室内に一脚の机が

$\mid$\begin{tabular}{cc} 
B-域 & $\begin{array}{c}\mathrm{C} \text {-域 } \\
\text { m-線 } \\
\text { 線 }\end{array}$ \\
\hline A-域
\end{tabular}

$\mathrm{Vp}$. あつてそれが左圖の如く配䚚されてるる。VL. 及び Vp. は實驗者及 び被驗者の座所を示し，交字の向きは机に對座の向きを示す。机上は i் $m$-線と $n$-線とに由りて $\mathrm{A}, \mathrm{B}, \mathrm{C}$ 三域に条たれる。A 域は課題が提出さ れる舞臺で，B域は課題すべき諸材料を準備せる處であり，C域はス

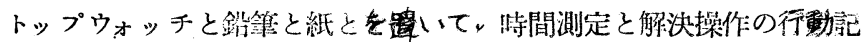


錄とを行ふ所である。n-線の上に小㣫立が置かれるから Vp.には C域に於ける VL. の所作は少しも解らない。

〔實驗の手續〕Vp. が著席すると先づ豫備課題が與へられ, 而る後, 本課題が與へら れる。(豫備課題本課題に就いては後述) Vp.は直ちに課題解決のために行動を開始する。 VI. は此の行動を用心深く觀察して出來るだけ詳しく記錄する。課題が解決されると 「どうやつた？」と間ふてV V . の內觀を求める。其報告がVp.の言葉通り記錄される。 實驗は全部で四回行はれたが，第二次實驗からは解決に著手と共にストップウォッチを 押し動かし，解答の報告と同時に押止めて其の經過時間を测定記錄する。

〔課題〕篥題は, 相互に大さを等しうする若干の事物を滓として提示するが，その 提示の仕方及び課題の仕組みに依つて次の如き $\mathrm{A}, \mathrm{B}, \mathrm{C}$ 三系例九問が設定された。

\begin{tabular}{|c|c|c|c|c|}
\hline \multirow{2}{*}{\multicolumn{2}{|c|}{$\begin{array}{l}\text { 課夏の } \\
\text { 系列 }\end{array}$}} & 課 題 の & 作 り 禚 & 課題の仕組 \\
\hline & & 群殖素夻提示する條件 & 群の提示の化方 & $\begin{array}{l}\text { 群要素—群(听) } \\
\text { (豆)の數—o 數 }\end{array}$ \\
\hline A & & $\begin{array}{l}\text { 見たり觸れたりするこ } \\
\text { とが容易に出來る場合 }\end{array}$ & $\begin{array}{l}\text { 紐通し玩具の球を群に } \\
\text { して紐にてつなぎその } \\
\text { はま提示する }\end{array}$ & (小) $3 \longrightarrow 6$ (大) \\
\hline B & $\begin{array}{l}a \\
b \\
c\end{array}$ & $\begin{array}{l}\text { 見たり䮷れたりするこ } \\
\text { とが出來るがそれが稍 } \\
\text { 因難となりたる場合 }\end{array}$ & 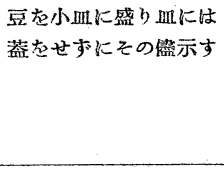 & $\begin{array}{l}\text { (小) } \begin{cases}2-4 & \text { (小) } \\
3-8 & \text { (大) }\end{cases} \\
\text { (大) } \begin{cases}6-3 & \text { (小) } \\
7-8 & \text { (大) }\end{cases} \end{array}$ \\
\hline $\mathrm{C}$ & $\begin{array}{l}a \\
b \\
c \\
d\end{array}$ & $\begin{array}{l}\text { 見ることも䪅れること } \\
\text { あ不可能なる場合 }\end{array}$ & 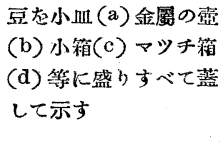 & $\begin{array}{l}\text { (小) } \begin{cases}2-4 & \text { (小) } \\
3-8 & \text { (大) }\end{cases} \\
\text { (大) } \begin{cases}6-3 & \text { (小) } \\
8-7 & \text { (大) }\end{cases} \end{array}$ \\
\hline
\end{tabular}

[課題の仕方]、課 題は, その目的よりし て豫備課題と本課題と に分机る。

課題 $\mathrm{A}$ ：豫備課題 一一紐通し玩具の球 と立方體との數珠つ なぎを Vp. の面前 に置いて「コレハ何 ト云フモノダ？」と 問ふ。Vp. の興味を

「何」一命名の方向一轉ぜしめ, 球群と立方體群とが交互になつて列を成してるること を注目させようとした。

本課題—「ココニ圆イ（球群を指す）ト四角イ（立方體群を指す）トガ並ンデ キルデセウ。コノ中デ圆イノダケハ皆デ幾ッアリマセウネ」と發問して其の後の行動を 觀察する。

課題 B：豫備課題一空の小血をVp. の面前 (上圖A域) に置いて豆を所定數だけ數 へて入れさせ，全部の血に入れ終るとVL.は之を上圖B域に移す。Vp.に「眼ヨッブ ツテ!」と命じた後で, A域に課題の所定數だけ今の小且を並列する。

本課題一「ドノオ㿼二モ2ッ(或は $3 \% 6 \% 8 \%$ )ッ゙ッッテキマスネ」と先づ念を 押すと，Vp. は閉目のまま首肯づく。VL. は直ちにつづけて「ッンナラ, サア眼 ヨ開

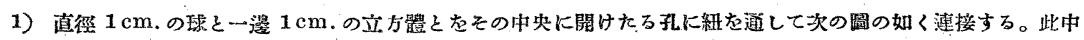
球體の總數を求めさせる。 
ケテ,コレダケミンナデ豆ハ幾ツアリマセウネ」

課題C : 豫備課題一一所定の數だけ豆を入れたる容器をVp.の前に置いて,「豆八幾:

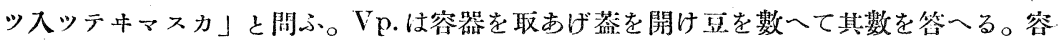
器の嗌をさせ，それを左手前方へ片付けさせる。VL.は炏の容器を取つて「コレニハ？」 と問ひ乍ら右手前方に置く V p.は之を取り茦を外して豆の數を签へる。友手前方に容 器を片付ける。かくして 全部の容器の豆の數が調べ終ると本課題が與へられる。若し Vp.が數へ誤つて他の數を签へたならば,「エ、ッ？ ヨーク調べテ御鹠！」と言つて再 調查を命ずる。課題 dではマッチの究箱にオハジキが入れてあるが, 何れも皆 8 個入で はなく，4個入 5 個入の箱が 1 倜宛むつて, 其等の箱は 8884858 の順序に與へられ る。全部の箱の調查が濟んだ後, 不足の箱には別のオハジキを補足して, どの箱も皆 8 個入であることを納得させてから本課題に移る。

本課題一一豆の數が調べ終つた時には, 容器はVp.の面前 (上圖 A 域)に正しく並 列されてみる。そこで直ちれVL.は「サアッレデハミンナ（と云つて容器の列を指す） デ豆(メはオハジキ) ハ戗ッアリマセウネる」と課題する。

以上は第三次實驗までの課題及び其仕方で, 向ほ外に第四次の實驗の課題及其仕方が あるが，てれはその項で揭示する方が便宜と考へるが故に此處には記さない。但し其課 題の仕方は課題 $\mathrm{B}$ の仕方に同じい。

〔實驗日】實驗は全部で四回施行された。其の時日は次の通りである。

第一包：昭和 9 年 6 月 $26-27$ 日 (第一學期中頃)

第二包：同年10月19- - 22日（第二學期中頃）

第三包 : 同年12月13-15日（第二學期終頃）

第四包：こ扎は補充實驗で，昭和10年 2 月 $8-12$ 日 (第三學期)

如上の實驗時期の相違は被驗者達の算術能力の相違を物語るものであつて, 後の考察 に重要なる關聯を有つてるる。

〔被驗者】山谷墟小學校二年生 8 名と一年生 7 名。一年生は第匹次の補充寶驗に參 加しただけである。三年生 8 名は㫮同一のクラスで其第二組である。一年生 7 名の中 3

\begin{tabular}{|c|c|c|c|c|c|c|c|}
\hline \multirow{2}{*}{\multicolumn{2}{|c|}{ 成績傾位學 }} & 二 & 作 & \multicolumn{2}{|c|}{$\rightarrow$} & \multicolumn{2}{|l|}{ 年 } \\
\hline & & 三 & 組 & $\rightarrow$ & 組 & $=$ & 組 \\
\hline 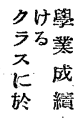 & $\begin{array}{l}\text { 上 位 } \\
\text { 中 } \\
\text { 下 位 } \\
\text { 下 }\end{array}$ & $\begin{array}{l}\text { Is } \mathrm{Se} \\
\mathrm{N} \mathrm{Ha} \\
\text { A } \mathrm{Hy}\end{array}$ & $\begin{array}{l}\mathbf{E} \\
\mathrm{M}\end{array}$ & $\begin{array}{l}\text { Ko } \\
\text { To } \\
\text { Iw }\end{array}$ & & $\begin{array}{l}\mathrm{Si} \quad \mathrm{Y} \\
\mathrm{Ta} \mathrm{Ka}\end{array}$ & \\
\hline
\end{tabular}
名は第一組で 4 名は第二組である。此 等の被驗者達は學業成績の上なる者, 中なる者, 下なる者といら標準に從つ。 て，學級擔任の先生から選出された。 故に人數こそ少いが，この點でクラス や學年全般を代表し得ると考へ得て實驗結果が一方に偏倚してるないことを信賴するこ とが出來る。被驗者の學年及組を示すと上表の通り。 


\section{III. 實驗の結果}

\section{1. 第一次惯驗結果}

如上の賽驗結果から誤答の頻數及び其の量觉調查すると第一表に見る通りである。郎 ち之に由ると

第一姜 第一次實驗に於ける誤りの頻數

\begin{tabular}{|c|c|c|c|c|c|c|c|c|c|c|c|c|}
\hline \multicolumn{2}{|c|}{ 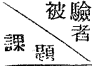 } & Is & $\mathrm{Se}$ & $\mathrm{E}_{\mathrm{H}}$ & $\mathrm{Ha}$ & MI & A & $\mathrm{Hy}$ & $\Delta$ & $B$ & $\triangle$ & $\square$ \\
\hline \multicolumn{2}{|c|}{ A } & & $\triangle_{+3}$ & & & $\Delta_{+1}$ & & & 2 & +4 & 2 & +4 \\
\hline \multirow{4}{*}{ B } & a & & & & & & & & & & \multirow{4}{*}{6} & \multirow{4}{*}{ \pm 15} \\
\hline & $\mathrm{b}$ & & & & $\triangle_{+4}$ & $\triangle_{+1}$ & ${ }^{\Delta}+1$ & & 3 & +6 & & \\
\hline & $\mathrm{c}$ & & & & & & & & & & & \\
\hline & $d$ & & $\Delta_{+6}$ & & & $\triangle$ & & $\triangle_{-1}$ & 3 & \pm 9 & & \\
\hline \multirow{4}{*}{ C } & a & & & & & & & & & & \multirow{4}{*}{4} & \multirow{4}{*}{ \pm 9} \\
\hline & $\mathrm{b}$ & & & $\triangle_{-3}$ & & $\triangle_{-3}$ & & & 2 & -6 & & \\
\hline & $c$ & & & & & & & & & & & \\
\hline & $\mathrm{d}$ & & & & $\triangle_{+1}$ & & $\triangle_{+2}$ & & 2 & +3 & & \\
\hline \multicolumn{2}{|c|}{$\triangle$} & & 2 & 1 & 2 & 4 & 2 & 1 & \multirow{2}{*}{12} & \multirow{2}{*}{ \pm 28} & \multirow{2}{*}{12} & \multirow{2}{*}{ \pm 28} \\
\hline & & & +9 & -3 & +5 & \pm 7 & +3 & -1 & & & & \\
\hline
\end{tabular}

これよっ後の表に於こは「誤り」た「メ」の記號た以て示し「誤りの量」た 「口」た以て示す
(1) 誤りは課題 AにもB系列に 子 C 系列に良存在 する。其の賽數值 は異つてはるる が, 之を全解答數 との比で示すと $29 \%, 21 \%, 14 \%$ となつてA, B, $\mathrm{C}$ 三者の間には誤 答生起率に於て何 等の相荤がない。

(2) B及びC系 列に於ては, 夫々

其の $\mathrm{a}$ 及び $\mathrm{c}$ 課題には誤答がなく, 之に反して課題 $\mathrm{b}$ 及び $\mathrm{d} に の$ 久誤答が起つてるる。

（3）誤答の多少は個人的に相違してるる。Vp.Isでは全く誤りは無いが，Vp.Mでは 誤りは甚だ多い。誤答の數と被驗者の學業成績との間にはさして相關關係は無い㨾であ る。吾々の譟題は被驗者にとつては容易なるのであるからであらう。

誤りには偶然の誤りがあり得る。上記の結果にかかる誤りが如何程あるかは言明し得 ないが，ただ一回の實驗結果ではこの默を考慮の外に置くわけにはゆかない。そこでこ の默の吟味のために第二次實驗の結果を同一方針で整頓することが必要である。

\section{2. 第二次實驗結果}

次表に就いて次の事を讀み取ることが出來る。

(1) 誤答の數が前回に比へて激減してるる。數値について比較するならばョに減少し てるる。

（2）誤りはB系列に多く $\mathrm{C}$ 紊列に少く，そして課題Aには見られない。從つて表面的 には前回の結果 (その(1)) と相異寸るが, 然しB系列に誤多く C 系列に少いといら倳實 から，誤りが課題設是の條件に無關係に生起してるることが解る。 
第二表 第二次實驗に於ける誤りの表

\begin{tabular}{|c|c|c|c|c|c|c|c|c|c|c|c|}
\hline 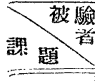 & $\mathrm{Se}$ & $\mathrm{E}$ & $N$ & $\mathrm{Ha}_{\mathrm{a}}$ & $\mathrm{M}$ & A & $\mathrm{Hy}$ & $\Delta$ & $\square$ & $\Delta$ & $\square$ \\
\hline $\mathbf{A}$ & & & & & & & & & & & \\
\hline a & & & & & & & & & & \multirow{4}{*}{3} & \multirow{4}{*}{+12} \\
\hline B & & & & & $\triangle_{+2}$ & & & 1 & +2 & & \\
\hline B & & & & & & & & & & & \\
\hline d & & $\stackrel{\Delta}{+8}$ & & & $\Delta_{+2}$ & & & 2 & +10 & & \\
\hline a & & & & & & & & & & \multirow{4}{*}{1} & \multirow{4}{*}{+4} \\
\hline \multirow[t]{3}{*}{$\mathrm{c}$} & & & & & & & & & & & \\
\hline & & & & & & & & & & & \\
\hline & & & & & & & $\Delta_{+4}$ & 1 & +4 & & \\
\hline$\Delta$ & & 1 & & & 2 & & 1 & \multirow{2}{*}{4} & \multirow{2}{*}{+15} & \multirow{2}{*}{4} & \multirow{2}{*}{+16} \\
\hline$\square$ & & +8 & & & +4 & & +4 & & & & \\
\hline
\end{tabular}

（3）誤りはB及 び $\mathrm{c}$ 系列の $\mathrm{b}$ 及び d課題に現は机て るる。

(4) Vp.Mには 前回の如く最も多 くの誤答がある。 Vp. A は學科成績 はクラスの下位に 居るのに誤りはな く, Vp. Mは中位 に居り Vp. E は

上位に居るのに誤りが女る。郎セ，誤りは學科成績に關係なく起るものである。

以上の結果から次の事實を指摘することが出來る。

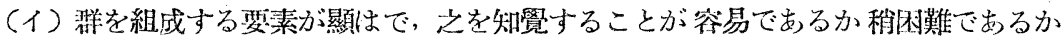
或は全く不可能であるか等の課題提亦の條件の差異は, 吾々の被驗者洼には殆しど重要 な意辀を有しない。

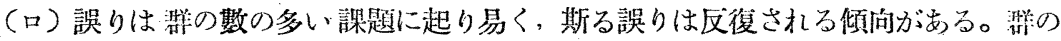
數が少ければ唯目身はやや大であつても誤りは少く又は全く起らない。

（ハ）誤りは學科成績とは直接的には關係少なに起る。それは言ふまでもなく課題が 甚だ容易であることに基づくのであらう。然らば何故誤りがなされなかといふことは。 吾々の與味を若くことで女る。

誤りの生起が課題提示の條件に依存し，所與刑の數多い課題には誤りが起り㚙く，而

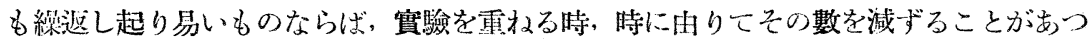
ても，それが消滅することはない等でむる。果して然らば，實驗が更に反復されたなら， ばその結果はどうでむらうか。

\section{3. 第三次兾騟結果}

ここでは結果はすべて正答で誤りは一件だも無い。のみならず課題の解決時間も前記 よりも遥かに短縮して第三表に示す通りである。特に注目すべきことは課題 $\mathrm{Bd}$ と Cd とに於ける時間短縮の事實で，換言す机ば，それに由つての平均錯差の著しい減縮の事 實で, 課題解決が一樣的に短時間で行は狄たことを示してるることである。そしてもし この點を强調するならば, 課題解決の困歏さが, 或は誤りが, 課題の特殊なる構造に值存: ナると指摘したことに何程かの修正が加へられればならぬかと思はれることである。勾 
論 $\mathrm{Bd}, \mathrm{Cd} \sigma$ ○問 第三表 每實驗に於ける各摖題解決時間平均

の解決時間は纷和 程か辩護の役を勤 めてるるものの, $\mathrm{Cb}$ の解決時間は 其役を拒絕するか

\begin{tabular}{|c|c|c|c|c|c|c|c|c|c|c|c|}
\hline \multirow{2}{*}{ 触 } & \multirow{2}{*}{ A } & \multicolumn{4}{|c|}{ B } & \multicolumn{4}{|c|}{ C } & \multirow{2}{*}{ 平均 } & \multirow{2}{*}{$\begin{array}{l}\text { 本均 } \\
\text { 錯差 }\end{array}$} \\
\hline & & a & b & c & $\mathrm{d}$ & $a$ & b & $\mathrm{c}$ & $d$ & & \\
\hline I & & & & & & & & & & & \\
\hline II & 8.1 & 5.5 & 18.8 & 8.9 & 28.0 & 7.6 & 14.6 & 4.1 & 51.1 & 15.5 & \pm 8.0 \\
\hline III & 6.8 & & & & 13.0 & 7.0 & 8.0 & 4.5 & 11,9 & 8.4 & \pm 3.7 \\
\hline
\end{tabular}
に思へる。して見ると $\mathrm{Bd}, \mathrm{Cd}$ の解決の困難さはその構成條件たる所與螌の多數に依る のではなく，何か他の條件に依るものであるかも知孔ない。

與へられる群の數少いるのは, 求めらるべき群要素の總數は小さく, かかる課題の解 決が容易であることは言らまでもなく, 之に反し所與羣の多い課題は, 求められる群要 素の總數が大となるから，解決に困蜼し誤りをも起し易いといふことは當然である。し てみると $\mathrm{Bd}, \mathrm{Cd}$ の課題の解沈の困踑さは, 所與群の多數に依るよりは總數の多數に依 るのでむるかも知狄ない。果してそ札は事實かどうかを检するために, 次の赛驗を試み た。

\section{4. 第四次實驗}

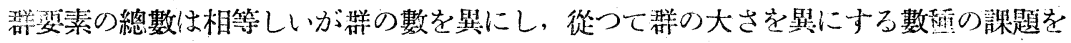
設定して，其の解決の難易を吟味せしとする。

此目的のために課題設定方針を次の如く定めた。郎ち，A）群の大さを小・中・大 の三階とし；B）群の數を 少・稍多・多 と三段とし：兩條件の組合せから次の8種 の課題を設定した。群の大さを豆の數で示し，群の數をそれを盛る肘の數で示して兒る

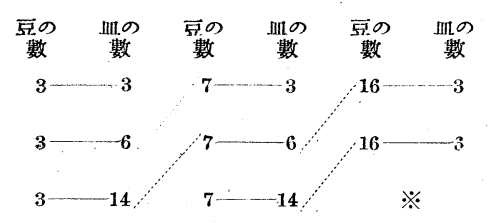

※ここには16—14の問琵が有る管であるが、そ の結果は 200 越えて極端に大となら、被驗著た 勞することが甚しい所から省略した。
と，斜方向に結果を相等しうする三組の問題群 を所有することになる。

問題間には難易の差が特に著しいから，乙を 提出する順序が解氿過程に影響することがある か女知机ないと考へて，それを吟味するため に, 次の如く二樣の課題系列を作つた。
A 系列 $(3,3)(3,14)(3,6)(7,6)(7,3)(7,14)(16,3)(16,6)$
B系列 $(7,6)(7,3)(7,14)(16,3)(16,6)(3,6)(3,14)(3,3)$

此課題采列に應ずるために被驗者達をも二組に分けた。

二年： A 組, Se Hy

乃組, Is $\mathrm{N} H \mathrm{Ha}$

一年 A組, Y Ko Ta jw

B組, Si Ka To 
第四表 第四次實驗(イ)に於ける誤答の頻數

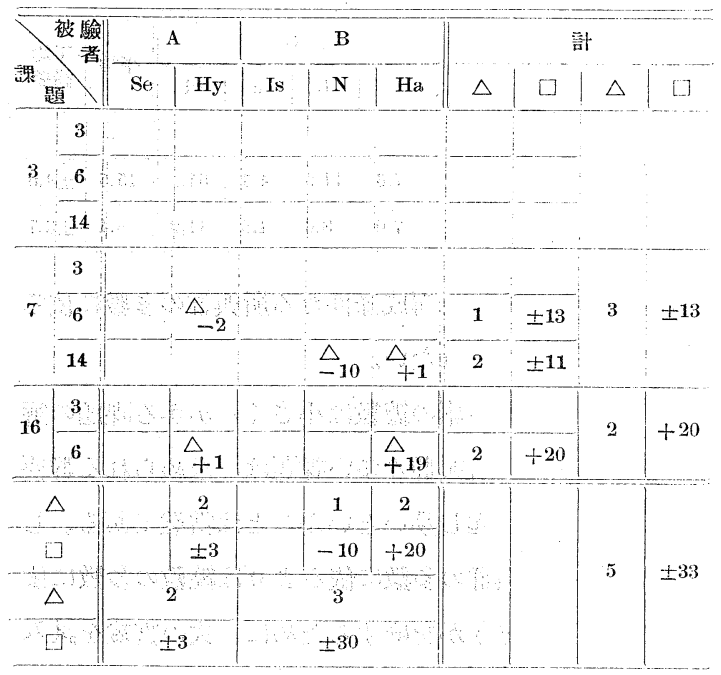

亿)二年生の結果 以上 の實驗の結果から誤りの解 答を拾ひ出すと, 第四表に 示寸如く，其の藪は甚だ少 く從つて一般的な言明は差 空へね杖ならない。关れに しても誤りが $(7,14)\}(16$, 6)と $(7,6)$ Łの三間にだけ 起つてるることは注目すべ き事である。

裸題解決時間の長短は解 決の蜼易を報ずるよき手引 でむる。そこで上記の課題 の解決時間を調べて見ると

第五表 第迈次實驗(イ)に於ける課題解決時晶

\begin{tabular}{|c|c|c|c|c|c|c|c|c|c|}
\hline \multirow{2}{*}{\multicolumn{2}{|c|}{ 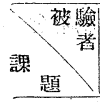 }} & \multicolumn{2}{|c|}{$\mathrm{A} \quad$ 縕 } & \multicolumn{3}{|c|}{ B $\quad$ 組 } & \multicolumn{2}{|c|}{ 棓 } & \multirow{2}{*}{$\frac{(\text { 秒) }}{A+B}$} \\
\hline & & $\mathrm{Se}$ & $\mathrm{H}_{\mathrm{y}}$ & Is & $\mathrm{N}$ & $\mathrm{Ha}$ & A & B & \\
\hline \multirow{3}{*}{3} & 3 & 2.5 & $\begin{array}{r}48 \\
\square .8\end{array}$ & 1.2 & 2.8 & 1.3 & 7.3 & 5.3 & 2.5 \\
\hline & 9 & 4.2 & 14.8 & 2.0 & 4.2 & 4.2 & 9.5 & 3.5 & 5.9 \\
\hline & 14 & 18.6 & 24.6 & 11.8 & 9.5 & 14.5 & 21.6 & 11.9 & 15.8 \\
\hline \multirow{3}{*}{7} & 3 & 1.5 & 6.4 & 1.3 & 23 & 2.8 & 3.9 & 2.1 & 2.9 \\
\hline & 6 & 9.0 & 33.6 & 2.5 & 7.3 & 8.0 & 21.3 & 5.9 & 12.1 \\
\hline & 14 & 33.8 & 67.2 & 10,2 & 39.2 & 65,3 & 50.5 & 38.2 & 43.1 \\
\hline \multirow{2}{*}{16} & 3 & 5.3 & 27.6 & 4.0 & 9.0 & 22.3 & 16.5 & 11.8 & 13.6 \\
\hline & 6 & 11.2 & 58.6 & 13.2 & 28.7 & 43.7 & 34.9 & 28.5 & 31.1 \\
\hline
\end{tabular}

第五表に示与通りでむる。

（）先づ表についてA 組とB 組の時間を比べると, 各課題に 於てB組は短時間を元してるる が，之は呥に參加者の個人差璐 示すもので,ここでは電要なこ とではない。たとひ數值は異つ ても $\mathrm{A}$ 組に於て特間の延びてる る課題はB組に於ても亦洔間が 延びてるる。郎ら此の事賽は，

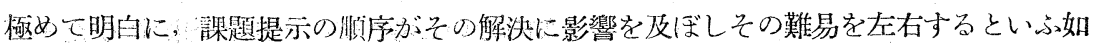
きことがないことを語つてるる。

(2) 所要時間は $(7,14)$ に於て最も長く, $(16,6)$ が之に次ぎ, $(3,3)$ に於て最も短い。 今この數値の大さに從つて順序づけると次の如く困難度を定めることが出來る。 I. (7, 14) $(16,6) ; 2 .(3,14)(16,3) ;(7,6) ; 3 .(3,6)(7,3) ; 4 .(3,3)$

此順序はA組犬゙けについて子B組だけについても啗嵌まる。而して此 1. 2. 3. 4. 各群 は恰度その順序に結果の大さを減少し, 第 1 群に最大で第 4 群に最小になつてるる。此 事實からして求めらるべき結果の總數が大であればある程, かかる課題の解決仙困難で あると云へるでむらう。 
(3) 更に第一, 第二, 第三各洋を見ると, 大體に於て, 群の數の多い課題は, 群の數 は少く群の大なる槑題よりも解炏に多くの時間を要し一層困䧼であることを示してる る。

（3）の事實によつて本實驗の最䘞に期待したる所のものは明確に實證せられた譯です る。け扎ども上記の結果では, 誤りの數が甚だ少かつたがために, 課題の特殊なる構造 と誤りとの關係について知ることが出來なかつた。瓂しその被驗者達は二年生で，これ らの課題にはさして团期を感じないが故であらうから，同じ課題を計算にもつと末熟な る一年生に課したるならば，むつと多くの誤りを生ずるであらうし，それによつて課題 の檴造と誤りとの關係杂更に泍く明瞭にすることが出來るのではあるまいか。かくして 一年生達に施した實驗の結果は次の如くである。

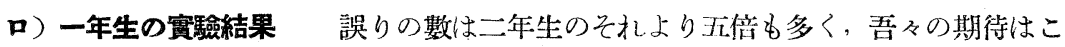
こで允分に達せら れた。

(1) A 組とB組 とでは誤りの數は 15 と 10 と相違して るるけれどる，そ れは各組の成員數 の相逵によるもの で, 之を一人の平 均に位すと 3.7 と 3.3 となつて剈一 致する。これに由 つて棓果題提出の順 序が解決の難罗。 第六表 第四次實驗(口)に於ける誤答の頻數

\begin{tabular}{|c|c|c|c|c|c|c|c|c|c|c|c|c|}
\hline \multirow{2}{*}{\multicolumn{2}{|c|}{ 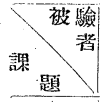 }} & \multicolumn{2}{|r|}{ A } & \multicolumn{2}{|c|}{ 組 } & \multicolumn{3}{|c|}{ B } & \multirow{2}{*}{$\triangle$} & \multirow{2}{*}{$\square$} & \multirow{2}{*}{$\triangle$} & \multirow{2}{*}{$\square$} \\
\hline & & $\mathrm{Y}$ & Ko & $\mathrm{Ta}$ & Iw & $\mathrm{Si}$ & $\mathrm{Ka}$ & To & & & & \\
\hline \multirow{3}{*}{3} & 3 & & & & & & & & & & \multirow{3}{*}{5} & \multirow{3}{*}{ \pm 5} \\
\hline & 6 & & & & & & & & & & & \\
\hline & 14 & & $\triangle_{+1}$ & $\triangle_{+1}$ & $\triangle 1$ & $\triangle_{+1}$ & $\triangle_{+1}$ & & 5 & \pm 5 & & \\
\hline \multirow{3}{*}{7.} & 3 & & & & $\Delta+1$ & & & & 1 & +1 & \multirow{3}{*}{11} & \multirow{3}{*}{ \pm 76} \\
\hline & 6 & & & & $\triangle_{+2}$ & $\triangle_{-1}$ & $\triangle_{+5}$ & & 3 & \pm 8 & & \\
\hline & 14 & $\triangle_{111}$ & $\triangle_{+3}$ & $\triangle_{+4}$ & $\stackrel{\triangle}{+7}$ & $\triangle_{-9}$ & $\triangle_{+31}$ & $\Delta_{-2}$ & 7 & \pm 67 & & \\
\hline \multirow{2}{*}{16} & 3 & $\begin{array}{c}\triangle \\
+8\end{array}$ & $\triangle_{10}$ & $\Delta_{+1}$ & & & & $\triangle$ & 4 & \pm 25 & \multirow{2}{*}{9} & \multirow{2}{*}{ \pm 67} \\
\hline & 6 & ${ }_{+18}$ & $\triangle 11$ & $\triangle_{-4}$ & & $\triangle 1$ & $\triangle$ & & 5 & \pm 42 & & \\
\hline \multicolumn{2}{|c|}{$\triangle$} & 3 & 4 & 4. & 4 & 4 & 4 & 2 & \multirow{4}{*}{25} & \multirow{4}{*}{ \pm 148} & \multirow{4}{*}{25} & \multirow{4}{*}{ \pm 148} \\
\hline L. & & +37 & +25 & \pm 10 & \pm 11 & \pm 12 & \pm 45 & \pm 8 & & & & \\
\hline \multicolumn{2}{|c|}{$\triangle$} & \multicolumn{4}{|c|}{$15(3.7)$} & \multicolumn{3}{|c|}{$10(3.3)$} & & & & \\
\hline \multicolumn{2}{|c|}{ : } & \multicolumn{4}{|c|}{ \pm 83} & \multicolumn{3}{|c|}{ \pm 65} & & & & \\
\hline
\end{tabular}
何程の影響をも及ぼさないといふことが明かで, 誤りが課題の構浩によつて起ることが 指摘される。

(2) 誤りは (7,14) (16,6) に最も多く, $(3,14)(16,3)(7,6)$ は之につぎ，(7,3) にはた だ一回で, $(3,6)(3,3)$ には誤りはない。之によつて誤りは結果の大なるべき課題に起り 易いといふことが出來る。

(3) 誤りは $(7,14)$ に最も多く,(16,6) では之につぎ, $(3,14)$ に多くして $(16,3)(7,6)$ では之に次ぐ等の事實から, 群の數多い課題は, 洋は大きくて潾の數の少い課題よりも 誤りを起し易いといふことが明確に㝘はれ得る。 
以上のことは, 二年の結果に於て解決時間から見た課題の付䧼度について語つた所と 全く一致する。更にこの誤りの考察に於て注目すべきことは誤りの量に關してである。

(4) $(3,14)$ と $(16,6)$ とは共に5回の誤りでありながら, その量は㙷著に異り, $(16,3)$

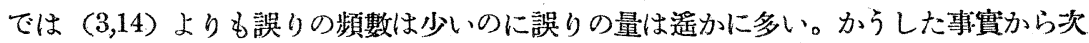
の如く言へるであらう。群が小さく然し群の數の多い場合には誤りの頻數は多いがその 高は少い。群が大きく然し群の數の少い場合には誤りの頻數は少くとも誤りの高は多 い。前者では小刻久を特色とし，後者では大刻之を以て特色としてるる。

解決時間について見るならば第七表に示すが如く，二年生のそれについて考察したと，

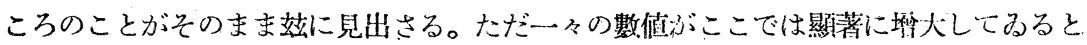

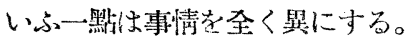

第七表 第凹次璂驗(口)に於ける課題解洺時間!

\begin{tabular}{|c|c|c|c|c|c|c|c|c|c|c|c|}
\hline \multirow{2}{*}{\multicolumn{2}{|c|}{ 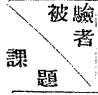 }} & \multicolumn{2}{|c|}{ A } & \multicolumn{2}{|c|}{ 組 } & \multicolumn{2}{|c|}{ B } & \multirow[b]{2}{*}{ To } & \multicolumn{2}{|c|}{ 舟 } & 均 \\
\hline & & $\mathbf{Y}$ & Ko & Ta & Iw & $\mathrm{Si}$ & $\mathrm{K} a$ & & $A \cdot$ 維 & 13 組 & $(A+13)$ 組 \\
\hline \multirow{3}{*}{3} & 3 & 1.6 & 3.5 & 5.5 & 2.8 & 2.0 & 4.5 & 3.0 & 3.4 & 3.2 & 3.3 \\
\hline & 6 & 3.0 & 7.0 & 8.3 & 14.2 & 24.3 & 9.0 & 16.4 & 8.1 & 16.6 & 11.7 \\
\hline & 14 & 18.3 & 20.4 & 28.6 & 67.3 & 72.6 & 19.4 & 82.6 & 33.7 & 58.2 & 44.2 \\
\hline \multirow{3}{*}{7} & 3 & 15.3 & 7.6 & 13.6 & 9.3 & 15.6 & 3.5 & 13.2 & 11.5 & 10.8 & 11.7 \\
\hline & 6 & 25.3 & 193 & 21.4 & 53.3 & 83.2 & 24.4 & 32.5 & 29.8 & 45.7 & 37.1 \\
\hline & 14 & 78.3 & 53.5 & 62.3 & 133.1 & 158.2 & $149.4^{\prime}$ & 97.5 & 81.5 & 135.0 & 104.6 \\
\hline \multirow{2}{*}{16} & 3 & 22.2 & 9.0 & 2.5 .0 & 29.3 & 49.2 & 20.7 & 33.4 & 20.8 & 34.4 & 26.7 \\
\hline & 6 & 31.4 & 32.4 & 52.1 & 77.4 & 135.2 & 40.2 & 97.5 & 48.4 & 91.0 & 66.7 \\
\hline
\end{tabular}

\section{IV. 結果の考察}

\section{1. 課題を解決する方法の改善}

同一の課題を全く同一の條件の下に提示したのに, 其の解決結果は一年㠿と二年生と に於ては著しく相違し、後者では誤りの數は論ずるにも足らぬ程少數で僅かに全答數の 13\%を占めてるるのに對

し, 前者では之に數倍し て45\%を占めてるる。解 決時間について其の差㟟 はまた著しくて，次の圖 第八表 一件生と二年生の結果に於ける哭答の比較(百分率) に示される如く，一年生の各曲點は二年生のそれよりも常に見上げる程に遥かに高く， 從つて曲線の傾斜も倒るるかと見る迄に急である。

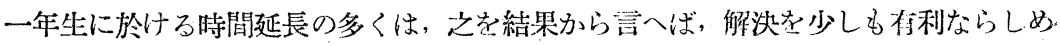


ては方ない謂はば徒爾なる時間延長であ 第 1 周 る。第九表は之を實證するもので, 時間の 延長する所そこに誤りが起きてるることを 示してるる。

然し乍ら，この事は一年生と二年生の實 驗成績の比較に於てのみ見られるものでは なく，第九表が示寸通り，二年生だけにつ? いても言はれることである。殊に二年生の 第一次實驗から第三次實驗に至る各實驗結 果を綜括的に見るならば，第十表に從つて 容易に察知し得る所である。第一次の實驗 結果では誤答數は全答數の19\%を占めてる たものが，第二次實驗結果では $\frac{1}{3} に$ 減少し 而して第三次實驗結果には一の誤答も存し ない。誤りが斯くの如く減少すると同時に 解決時間子亦大に短縮せられ, 各被驗者に 平均の一課題解決時閏平均は第二次實驗で は 15.5 秒であつたものが 8.4 秒に約坐㳦 し, 平均錯差孔亦 \pm 8.0 から \pm 3.7 となり て, 實驗參加者の誰もが一齊に解決時間を 短緶し, 個人差を少くして上成績を得たこ とを示してるる。

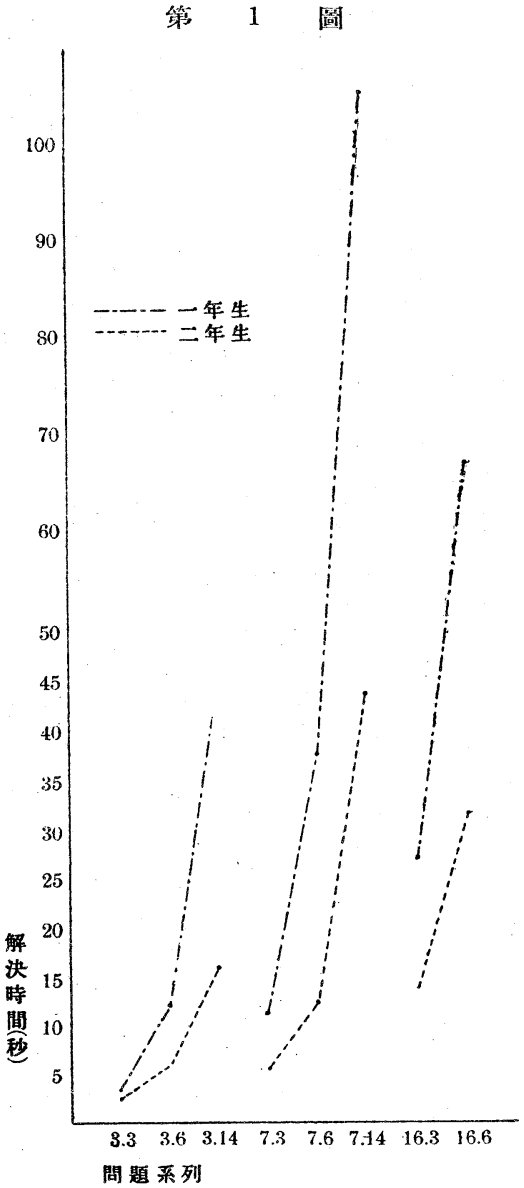

一年生と二年生とに於ける實驗成績の著しい差暴は，何故に起きたかの理由を彼等の 學力の差樭に歸するならば，事は極めて簡單に片付いてしまふ。けれども，それでは二

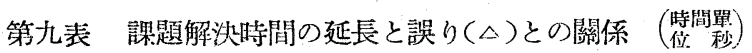

\begin{tabular}{|c|c|c|c|c|c|c|c|c|c|}
\hline \multirow{2}{*}{\multicolumn{2}{|c|}{ 浬 被驗者 }} & \multicolumn{3}{|c|}{3} & \multicolumn{3}{|c|}{7} & \multicolumn{2}{|c|}{16} \\
\hline & & 3 & 6 & 14 & 3 & 6 & 14 & 3 & 6 \\
\hline \multirow{3}{*}{ A } & $\mathbf{Y}$ & 1.6 & 3.0 & 18.3 & 15.3 & 25.3 & $\triangle 78.3$ & $\triangle 22.2$ & $\triangle 31.4$ \\
\hline & $\mathrm{Si}$ & 2.0 & 24.3 & $\triangle 72.6$ & 15.6 & $\triangle 83.2$ & $\triangle 158.2$ & 49.2 & $\triangle 135.2$ \\
\hline & $\mathbf{T a}$ & 5.5 & 8.3 & $\triangle 28.6$ & 13.6 & 21.4 & $\triangle 62.3$ & $\triangle 23.0$ & $\triangle 52.1$ \\
\hline 組 & Iw & 2.8 & $14 \cdot 2$ & $\triangle 67.3$ & $\triangle 9.3$ & $\triangle 53.3$ & $\triangle 133.1$ & 29.3 & 77.4 \\
\hline \multirow{2}{*}{ B } & Is & 1.2 & 2.0 & 11.8 & 1.3 & 2.5 & 10.2 & 4.0 & 13.2 \\
\hline & $\mathrm{Ha}$ & 1.3 & 4.2 & 14.5 & 2.8 & 8.0 & $\triangle 65.3$ & 22.3 & $\triangle 43.7$ \\
\hline 組 & $\mathrm{Hy}$ & 4.8 & 14.8 & 24.6 & 6.4 & $\triangle 33.6$ & 67.2 & 27.6 & $\triangle 58.6$ \\
\hline
\end{tabular}


第十表 第一次より第三次に至る旬實驗に於ける各被驗者の誤り(素中の杀は課題)

\begin{tabular}{|c|c|c|c|c|c|c|c|c|c|c|}
\hline \multirow{2}{*}{ 實羷 } & \multirow{2}{*}{ Is } & \multirow{2}{*}{$\mathrm{Se}$} & \multirow{2}{*}{$\mathrm{E}$} & \multirow{2}{*}{$\mathrm{N}$} & \multirow{2}{*}{$M$} & \multirow{2}{*}{$\mathrm{Ha}_{\mathrm{a}}$} & \multirow{2}{*}{$\mathrm{Hy}$} & \multirow{2}{*}{ A } & \multicolumn{2}{|c|}{ 詻 } \\
\hline & & & & & & & & & $\Delta$ & $\square$ \\
\hline I & & $\begin{array}{r}A-3 \\
\mathrm{Bd}-6\end{array}$ & $\mathrm{Cb}+3$ & & $\begin{array}{l}\mathrm{A}-1 \\
\mathrm{Bb}-2 \\
\mathrm{Cb}-3 \\
\mathrm{Bd}-2\end{array}$ & $\begin{array}{l}\mathrm{Bb}+4 \\
\mathrm{Cd}-1\end{array}$ & $\mathrm{Bd}-1$ & $\begin{array}{l}\mathrm{Bb}+1 \\
\mathrm{Cd}-2\end{array}$ & 12 & \pm 28 \\
\hline II & & & $\mathrm{Bd}-8$ & & $\begin{array}{l}\mathrm{Bb}-2 \\
\mathrm{Bb}-2\end{array}$ & & $\mathrm{Cd}-4$ & & 4 & -16 \\
\hline III & & & & & & & & & & \\
\hline$\triangle$ & & 2 & 2 & & 6 & 2 & 2 & 2 & 16 & \pm 44 \\
\hline $\mathrm{I}$ & & -9 & \pm 11 & & \pm 11 & -5 & -5 & -3 & & \\
\hline
\end{tabular}

第十一表 每:實驗に於ける各被驗者の一課題解決時間斗均 (秒)

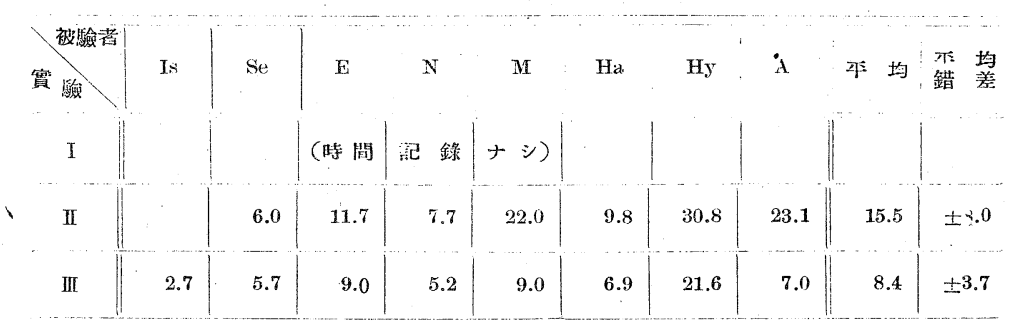

年生のみに見られる成績向上の事實をば解明することが出來ない。二年生に於ける成績 向上の事實を同一實驗の反復による效果に蹛して說明するならば，一年生と二年生との 成績の差暴を闈明寸ることが充分にゆか奴。それともこれとかれとは別々に䜅明して滿 足すべきであらうか。然らば一體賽驗反復の效果とは吾々の蛽驗では如何なる事實を指 すのでむるか。一年生と二年生との學力の相違といふことは一體如何なる事實を指すの であるか。上の三ッの事實が別々に解明されれねばなら奴といふ根據は一體何處に存する ものでせるか。

吾々の被驗者は, 學校成績がクラスの上位にある者, 中位にある者, 一位にある者よ り成つてるるが，この場合一作の上位に岕るものと二年の下位にもる者との學力の相違 を如何にして制別し得るだらうか。學力の相違を學年の相違と同義に用るようとするな らばその判別は容易であるが，それでは少し子事實の解明に役立た奴の久か却つて事實 を隐蔽するものとなる。

學力の相違を一ヶ年間の算術練㫘の差異といふ風に换言するならば，一年生と二年生 との成績の差異も二年生に於ける實驗反復による成績の向上も說明し盡されるかの樣に 見える。けれども吾々の實驗ではどの程度まで練㫘の效果を言ひ得ることであららか。 二年生に於ける實驗反復も第一次と第二次との間には夏季休堦を中に入れて約四ヶ月の 
日子を經過してるる。第二次と第三次との間にも約二ヶ月の時日が經過してるて，之等 の間には吾々の課題は被驗者から全く遠避けられてるた。それにも拘らず反復による練 既效果が上來見來りし如く顯著に現はれ得るものでむららか。確かに被驗者の中には第 二次，第三次の實驗に際してはその實驗材料を彼等の面前に取出すと,「斯ウイフノヨ前 ニモヤッタネ」とか,「コレハコノ前ヤッタノト同ジイノ？」とか話しかける者もむる が，このことはよし作業能率に少しも不利を辰すことはなかつたにしてもそれてたけのこ とで，それ以上に有效に助け䉆したららといふことは少しも確かでない。かかる不確か なるものに假托して事實の解明を糊塗することは出來ない。

ここで考ふべきことは被驗者達の學校に於ける學甭經過のことである。第一次の實驗 が課されたる第一學期中頃に於ては被驗者達は百以下の數の加算減算の練歪に熱心して るた。第二學期になると彼等は，始めて九九敎授を受け，第二次實驗は此の九九の聲全 部が恰度呚授され絵つた時に行はれた。第三次惯驗が課されたのは是より約二ヶ月の後

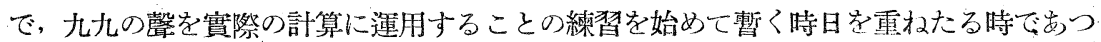
た。九九に關する被驗者達の知識は最初は殆んど白紙の狀態から, それが彩られ色濃く 塗り重ねられて行く其の時々をとらへて, 實驗は課されたのであるから, 此の結果が彼 の知識に色付けられることは當然のことである。實際, 第一次實驗では九九を用るて課 題を解決するといふものはなかつたのに，第三次の實驗では殆んど全部の被驗者が此の 方法で課題解沠を果したので女る。一年生と二年生とが同時に參加したる第四次の實驗 は第三學期のことで，二年生の九九練㫘は一㬄積まれた時であり，一年生は九九につい ては白紙でむる時で，この相違が彼等の實驗成績の異常なる相違を來たしたのだと云ふ. ことが出來る。此の實際を捕へて教師は敎授の效果だと言はうとし，生徒は亦學丕の 效果だと言はうとするならそれでよい。しかし之を第三者力゙學力の相違と言はうとする ならば, 前述の如く不徹底の語を以て非難せねばならぬ。第三者に觀察され得るものは 被驗者の課題解決の行動であり，實驗を重ねる每にこの行動形態が變容し改善されたと いらことであり，而もこ机は次に見る如く何入にも明白な事實であつて疑を容るる餘地， を残さない。

Vp. M 課題 $\mathrm{Bd}$

〔第一次實驗〕 イロハニホへトチ「7ッ」と小聲で言つて, 左手で(イ)を左方一少し

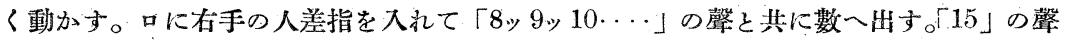

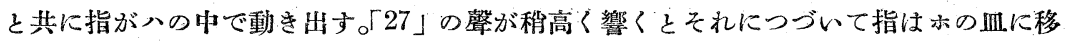
り,「34」の馨と共に指はホの四を出てへに移る「39」の㢣と共に深呼吸がなされる。 からトへ數へつづけられ,「48」の䠛と同時にチの四の中で指が上下に動き出す。54」の

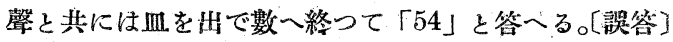




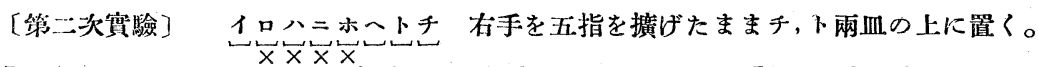
「7ト7トタシテ14」と言ふ。右手をホの前方（×印）に置く。「28デー28-28デ」と言 ふ聲が聞える。右手を二の前方（（＼cjkstart印）に置く。「 7 デモッテー-35」と小さく言ふ。右

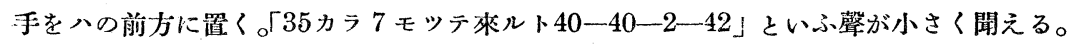
右手を口の前方に置く。 42 カラ 7 モテテ來ルト一」とまでであとは途切れた。やがて $\lceil-54 」 「 54$ 」聞える。最後の「54」は明かな们聲で解答である。〔諮答〕[時間50.2秒】 このあとで「今どらやつたか」と內觀を求めると次の如く報告する。「7ト7ト足シ テ」と言ひながら右端の二血を90度包轉して前後に並へ，次の二血の左方を右方の皿の 前方に移し (一_- - - 次の二四の右方を二列群に近的け, 左方をその前方に移して 洌を作りながら「マタ是レタマゼテ」と言ふ(一- - - - - $)$ 。そして「アト豆ヨ 一カタマリデ勘定シタ」と言ふ。他の皿には手を觸孔ない。

[经三次實驗]視線を左方の四から右方の四一（上圆イからチの方一）緩やかに轉

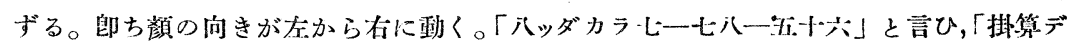
ヤッタ」と報告する。[時間 10.5 秒]

上例では課題解決の方法が實驗得に改善されてるる。初扎と次们の解答は共に誤りで もるからその進步のさまを數字を以て示すことは出來ないが，第二次實驗では前问の方 法の改善によつて解決時間を殆しど 5 に短縮し，立派に正答を果して實に日ざましい蕉 步学示してるる。若しもこの方法の改善がなかつたらこの進步は期街され得なかつたら 今。 Vp. Hy の例はその好適なるものである。

Vp.Hy 課題 Bd【籁一次實驗〕，第一の皿に右手を入孔，その人差指を伸して豆を 㨁接に接しながら數へてなる。第二の四に移る，同漛。第三の四からは右手の人差指が 緊張のまま皿の上䆘で七度づつ上下゙に動く。—「55」。と答へる（誤答）

[第二次實驗]椅子から立上つて顏を恰度皿の上に持つて行き, 右端の皿からその 中をのぞきながら一つづつ數へて行く。「56」と答へる，〔56.2秒]

[第三次實驗]右端から一四づつその中をのぞいて行く。20秒の頃顏が左方に行 く。また右端に杘つて且の中を一々のぞきながら數へて行く。「56」[正答了(時間50.2秒) 此の例では解決の方法は初包から第三次實驗に至るまで一向に改善されいな。誤りは 再びせられなかつたが，時間の短縮は甚だ僅少で，進步の跡は至つて映えない。反復の 效果咕なる學習の效果はここに於ても積極的に作用して居るのであららが，それだけを 以てしては決して顯著なる成績の向上を實現することは不可能である。一年生と二年生 との實驗成績の著しい差異は恰も Vp. M と Vp. Hy に於ける第三次實驗成績の差異の 如くで, 決して練習度や單なる學力やの差異に由るのでなくして解決方法の差異に基づ くのである。かくて次の如く結論することが出來る。 
誤謬頻數を減少せしめ解決時間を短縮せしめる主要なる條件は, 課題を解決する方法 の改善でもる。

\section{2. 群を處理すを態度}

課題の解決は與へられた豆の群を如何樣にか整頓し處理して豆の總數を把捉し、之を 課題者に報告することに由つて結了する。總數の把捉は群を處理する行動の必然的結果 で，把捉數の報告はそれに附隨することであるから，此課題解決に於ける最も本質的な るものは所與群を如何に扱ひ處理するかといふ點にもる。乃ち課題解決の方法は畢竟す 北ば所與群を處理する態度如何に歸着するのである。

課題として提示せられる群を如何に處理するかに就いては，何等の條件づけもしなか つたから, 被驗者達が自身に於て任意に決定する群處理の態度は甚だ多樣を極めて, そ

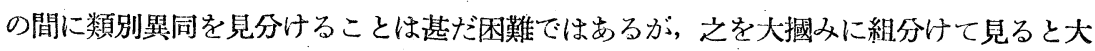
約次の四典に分類することが出來る。

I ．所與の群に全く無關心に處理する態度。

II. 群を理解し群を群のままに把握して處理する態度。

III. 群に手を加へ群の群を作りつつ處理をすす女て行く態度。

IV. 所與の群全體を統括し, 整頓して是等を同時に處理する態度。

四棧の是等の態度は，之を實際の行動記錄に由つて觀ると次の通りである。 第一の態度の例

Vp. A: (A) 右手の人差指を實物に附けて次の如く數へて行く。〔1ッ2ッ3ッ4\%” -18]

Vp. A (BaI) 血の上方で右手の伸びた人差指が上ドしながら次の順に動いた。 $\begin{array}{llll}8 & 6 & \dot{4} & 2 \\ \mathbf{4} & \mathbf{5} & \mathbf{3} & \mathbf{1} \\ & \llcorner & & \end{array}$

第二の態度の例

Vp. A (AII) 右から第二の群を握つて[6]と言ひ, 第三の群を握つて「ュレ デ 9 ダラウ」と言ひ, 第四群を握つて「コレデ12」, 第五群を握つて「コレデ15」,そして 最後の群を握つて〔18〕と有馨に言つて答へとする。

第三の態度の例

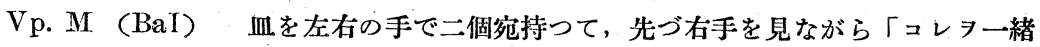
ニスルトッ」，と言ひ、それから左手を見て〔コレモ4ッ一ーデ 8ッ」「8ッを知るのにどう いふ風にやつた？」と尋ねると、先づ右手で右の二血を指し，次に左手で左の二血を指

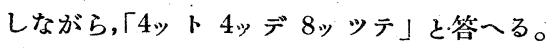
第四の態度の例上例

1）括孤中の女字は課題の系列, 口-ー、數字は實驗の順序を示す。 
Vp.Ha（AII）首が右から左へ動く。そして右端の群を左手の中指と人差指と で抑へて,「 3 ガネ」と言つたがあとは途切れる。首が復右から左へ向きをかへる。數一 てるる樣子である-—「6ッアルカラ，爷三18」

上例は何れも四種の態度の夫々典型的なるものである。實際に於ては上例の如きはむ しろ少くて，多くは是等の三三が混じてるる混合型である。(次例參照)

Ap. Ha ( $\mathrm{BcI}) \quad \Gamma 6$ ト 6 足シテネ 12 ニナッタノ。ダカラコッチ（左の端の箱を 指す）八 $12-13,14,15,16,17,18$ トヤッタ」

Vp. $\mathrm{Hy}(\mathrm{CbII})$ [37.3] 右端の二個を右手で同時に抑へて右方へ引き離し，次に

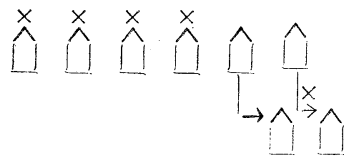
(メは右手作羁)

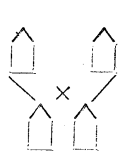

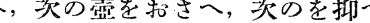
次のを抑一，之の間に $1,2,3-4,5,6-7,8,9-$

$10,11,12-12$ ト 12 デ 24 と答へる。

Vp. M (AIII) [17.3〕右から第二の群の處（黑點の處）から右手を右方一動か して「 $3 \%$ トッデ 6 ッ゙」と言ひ，その手を返一し第三第四の群の嗳を左方へ動かし

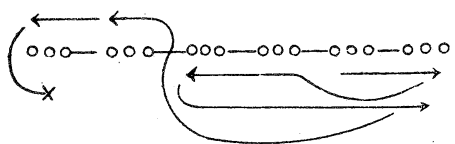

て「コレモ6 6 デ」と言ひ，其の手を右方へ第一 群まで返へして「アトュレダケデ12」と言ひ， その手を第五碓第六群の上空にて動かし，左方 前方に置き,「15,18」と數へつづけて答とする。

是等のうち，第一の例は，第二と第一のタイプを混じて居り，第二の例は第三と第一。 のタイプを第三の例は第三と第三のタイプを混じて居る。

以上四種のタイプと混合型とは，然らば相互には如何なる關係を有つものであらち か。混合型壱仔細に見ると第二のタイプに第一のタイプが混合し，第三のタイプに第二 又は第一のタイプが湝合してるる，各タイプは全く偶然に任意に混合してるるのではな く，一の態度が中途にして崩壞しそして他の態度に移り行くといふ風に見える。して見 ると混合型は他の四種のタイプの中間型であるかと思はれるし然らば四種のタイプは相 互に聯關するもので岕らればならぬ。吾々は先にVp.M の例に於て解決方法が每實驗 に改善する事實を見たが，このことよりしても四種のタイプは孤立的なるのではないら LW。

果して然らば四種のタイプには一から他へと聯關せる事實が見出されれる゙ならない。 而してそれは次の表に由つて明示される。郎ち，

(1) 第一次の實驗では第一のタイプ最も多く, 第二のタイプ之に次ぎ, 兩タイプを合 
ᄂて $3 \%$

第十二㳖 每實驗に於て現はれた四種の態度

を占めて

るる。

(2) 第

二次實驗

では第一

第二のタ

\begin{tabular}{|c|c|c|c|c|c|c|c|c|c|c|c|}
\hline 被酸 & Is & $\mathrm{Se}$ & $\mathbf{E}$ & $\mathrm{N}$ & $\mathbf{M}$ & $\mathrm{Ha}$ & Ну & A & & :- & (F) \\
\hline 態 度 & $\mathrm{I}|\mathrm{II}| \mathrm{I}$ & $\mathrm{I}|\mathrm{II}|$ & $|I I| I$ & $\mathrm{I}|\mathrm{II}| \mathrm{I}$ & $\mathrm{I}|\mathrm{II}|$ & IIII & $|\pi|$ & $\mathrm{I}|\mathrm{II}| \mathrm{III}$ & I & II & III \\
\hline
\end{tabular}

イプは著

しく淢少

\begin{tabular}{|c|c|c|c|c|c|c|c|c|c|c|c|c|c|c|c|c|c|c|c|c|}
\hline$I$ & & & \begin{tabular}{l|l|l|l|l|}
3 & 2
\end{tabular} & $2 \mid 1$ & $|5|$ & & & & 1 & 1 & & 4 & \begin{tabular}{l|l}
1 \\
\end{tabular} & $|8|$ & & 3 & & $38 \%$ & $14 \%$ & $12 \%$ \\
\hline II & ||$^{2}$ & & 1 & & $4 \mid$ & & & & & $5 \mid 2$ & 1 & $|3|$ & & $|1|$ & & $|6|$ & 1 & 35 & 6 & 4 \\
\hline III & $\mid 7$ & & & & & & & & : & \begin{tabular}{l|l}
3 & 7
\end{tabular} & 1 & $|2|$ & & & $2 \mid 1$ & & 2 & 19 & 18 & 4 \\
\hline \multirow[t]{2}{*}{ IV } & & $6 \mid$ & \begin{tabular}{l|l}
5 & 7
\end{tabular} & 75 & & $9 \mid 6$ & & $9 \mid$ & 6 & & 4 & & \begin{tabular}{l|l}
8 & 5
\end{tabular} & & & & $6 \mid 6$ & 8 & 62 & 80 \\
\hline & || $9 \mid$ & $|6|$ & \begin{tabular}{l|l}
9 & 9
\end{tabular} & 6 & $|9|$ & $9 \mid 6$ & & 9 & $6 \mid 9$ & \begin{tabular}{l|l}
9 & 9
\end{tabular} & $|6|$ & 9 & \begin{tabular}{l|l}
9 & 6
\end{tabular} & $|9|$ & \begin{tabular}{l|l}
9 & 6
\end{tabular} & 9 & \begin{tabular}{l|l}
9 & 6
\end{tabular} & 100 & 100 & 100 \\
\hline
\end{tabular}

混合型はこの表ではこの起始のタイプの內に組入れた。例へば第三と第二との混合型は第このタ イプとしたのである。

して，第四のタイプが大いに旜し，之のみで $62 \%$ を占め，第三のタイプと合せると $80 \%$ に上る。

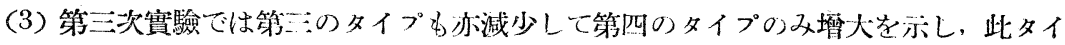

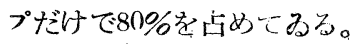

(4) 第一次實驗で第一第-.ののタイプが占めた所を第二次實驗では第三第四のタイプが 占領し, 第三次蕒驗では第四のタイプだけが占めたのである。此事實からして四種のタ イプは一の發展過程をなすといら點に於て不に聯關し，その過程を夫々段階づけて居 り，混合型はこの段階間に位置せしめらるべき中間型だすることを知る。

(ら)一々の被驗者について見ると、この發展の状況はV.p. E, V p. H の如く飛躍的で あるものもまり，Vp.Hy の如く發展を示さ好ものとあるけ机ども，Vp. M, Vp.Aに 於てはその經過が甚だ歷然としてるる。

同樣の考察を第四次實驗結果に及ぼすならば次表の結果を見出すのでせる。

(1) 一年生に於 第十三表 第四次實驗(イ，口)に於て現はれた四種の態度. ては第二のタイプ 最も多く，第一の タイプそに次ぎ， 兩者を合して75\% を占めてるる。

(2) 二年生に於

\begin{tabular}{|c|c|c|c|c|c|c|c|c|c|c|c|c|c|c|}
\hline \multirow{2}{*}{ 態學被驗都 } & \multicolumn{3}{|r|}{1} & \multicolumn{4}{|c|}{ 生 } & \multirow{2}{*}{ 棓 } & \multicolumn{3}{|c|}{2 年 } & \multicolumn{2}{|l|}{ 生 } & \multirow{2}{*}{ 訪 } \\
\hline & $\mathbf{Y}$ & $\mathrm{Si}$ & $\mathrm{Ka}$ & $\mathbf{T a}$ & Ko & $\mathrm{Iw}$ & To & & Is & $\mathrm{Se}$ & $\mathrm{N}$ & $\mathrm{Ha}$ & $\mathrm{Hy}$ & \\
\hline$I$ & & 4 & & 5 & & 7 & & $29 \%$ & & & & & 7 & $17 \%$ \\
\hline II & 3 & 3 & 3 & 3 & 8 & 1 & 5 & 46 & & & & 2 & & 5 \\
\hline III & 5 & & 5 & & & & 3 & 23 & & & & & & 0 \\
\hline IV & & 1 & & & & & & 2 & 8 & 8 & 8 & 9 & 1 & 78 \\
\hline
\end{tabular}

ては第四のタイプ犺部分を占め，78\%の數值を以て一年生の第一第二タイプに匹敵し てるる。

（3）二年生に於ける第一のタイプはVp. Hy にのみ見られたものであるが，此被驗 者が學科成績もクラスの下位に居る者であると知るならば, その理由も首肯けやら。第 四次の實驗に至つて明かに成䋶の影䠹が見出される。 
（4）一年生の場合には然しその影響は充分明かでない。上位に居るVp.Koには第二 のタイプが見られ、V V. Si には第一のタイプが過坐數を占めてるる。下位に居るVp.

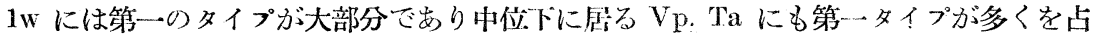
めてるること，上位の Vp. Y や山位の Vp. Ka，To には第二第: :のタイプが多い點で

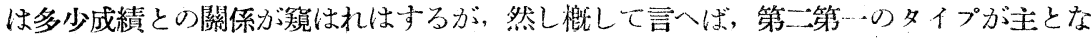
つてるて，學科成績の影響は少い。

（5）第十一表と第十 表とを比較すると一年生の事情は第一次實驗のそれに類似し， 二年生の事情は第二次實驗結果に類似してるる。後者の類似は同一被驗者の實驗結果で もるから當然のことでもるが，これに依つて一年生の結果と第一䔈驗結果の類似も办內 的に近似すると吾へるだらう。かくして一年生と二年生との實驗成績の著しい相違が， 及び二年生に於ける第一次から第 :次實驗に至る實驗成績の间上の事實が，同一の立場 から少しも矛盾なく解明されることとなる。

\section{3. 群に無關心なる態度}

豆が或は球體が明白に群として提示せられてるるのに，これには頓着せずに專ら其の 要素たる豆や球體に意を注ぎ，乙を直接の龉象として取扱び，課題を解決して行くのが 第一の態度である。取扱の上からは, 次の例に見る如く, 此の群の要素から彼の群の要 素へと直接に連りを結んでしまふから，此の羣彼の檗といら境界が作られで群提示とい ら竐果題性が無視されててるる。

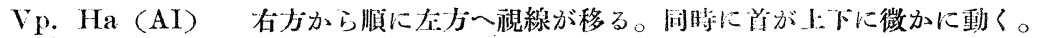
やがて「18」と签へる。VL.「どうやつたか」一「1，2，3，4，5，6，7，8…17, 18 トヤ ッタ」。

然し此態度では如何なる意味に於ても群としての所與條俳が常に無視されてるるとい

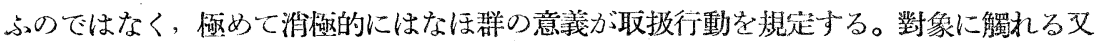
は指示する指の運動がこの群の要素から彼の群の要素に移る侍に大きく進み口から涅孔 る唱へもその度每に明かな休止をつくり，口と手の運動の小刻多と大刻久の交然する進 行が一種のリズムを形成する。次の例は蟨頭から漏孔て來る微かな言葉と共に, 首を上 下に運動しそれが一定の時間を捛いて休止することを示してるる。

Vp. Ha (AII) [6.4”] 首が上下に動く。同特に微かな箱がする。「6ッといふ聲が 聞える。首が三度動くと休止する。視線が左方へと向を移す。18」と签へる。VL。「ど

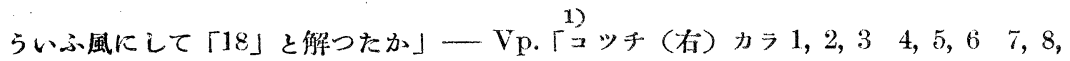
$9 \cdots$ …旁ひ作ら各群の球體を一々指示し个ら左端をで來る)トヤッタ」

1) 課題大解決した後で、VL.は多くの場合に「どういふ風にやつた?」と發問した。この發間は定句であるから

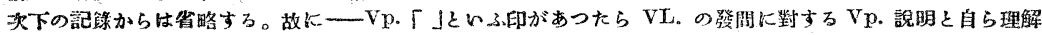

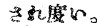


群に對する關心务可成に明师であつても， それ故に群としての取扱が直に實現するの ではない。

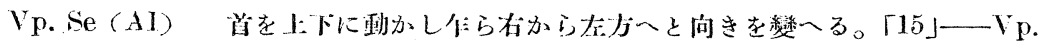
$\lceil 123456 \cdot \cdots 13,1415$ トトッターーアア!一17, 18ダ!」一-Vp.「ズット見テ行ッタラ ネ,コレ(ク站の亦色の群) ガアッタカラ」

「コレガ」と言つて指方ざれた群は, 赤の群としてでもるか, 左端の從つて「それいが最

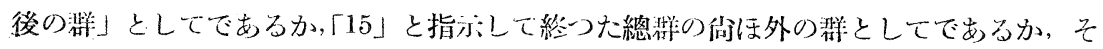

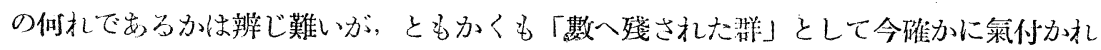
た。にも拘らげ此の群は未だ群としての报ひを受け得ず，要素がそこから取出されてそ 狄版报はれる。だせる。

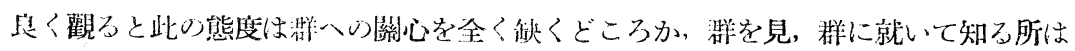

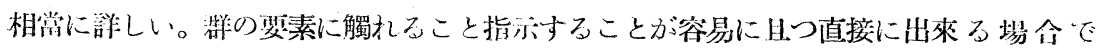

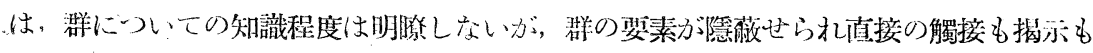

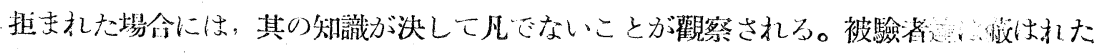

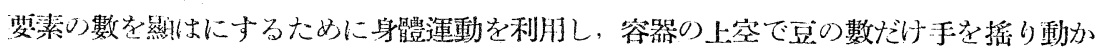
し，容器の傍で豆の數だけ机を吒き，或は頭首をトトに動かし或は容器を凝斻しイら小

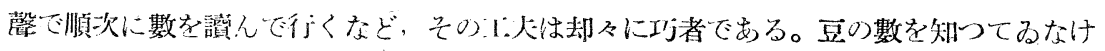

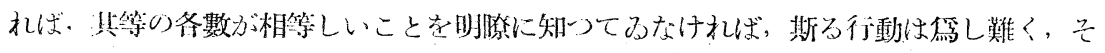

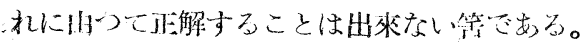

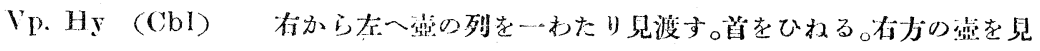

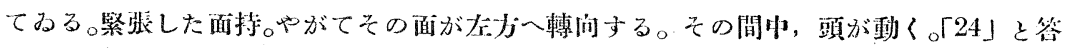

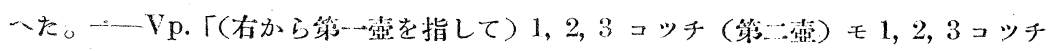

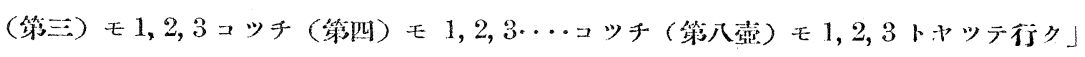
被驗者の說明は極めて明白に各脽の大さと, それら各臂の相等しさとを知つてるるこ とを證してるる。群に關与る知識は是程に豐かで, それてが解决を助ける功も大である

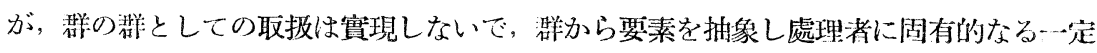
の處理方式に從つて取报ふののである。

與へられた群には關係なしに被驗者が自身で任意に群を作り，此の群を取披ひの對象 として處理する場合がある。任意に作る群と言つてもそれは定つて二個群である。同に は豆が何倜在つても招構しなしに二個宛を一鄀として,「 $2,4,6,8,10,2 \cdots \cdots$ と數へて 行く,

V p. Hy $(\mathrm{BcI})$ 在手の人登指と親指とを石端の皿の上方で少しく撗げ，その指

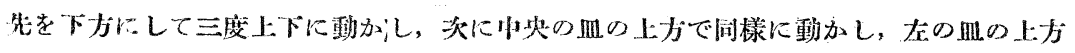


に移つて间柡に動作与る。18」と答一る。一Vp.「2, 4, 6, 8,トヤッタ」

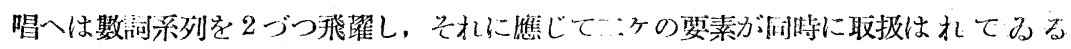

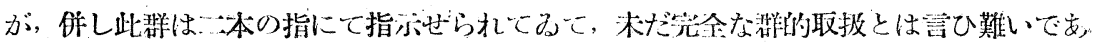
らう。然し，次の例では明かに衸的取报老成してるる。

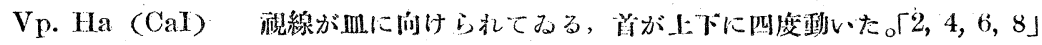

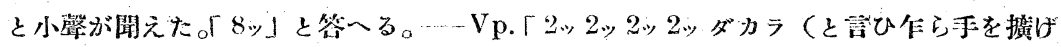

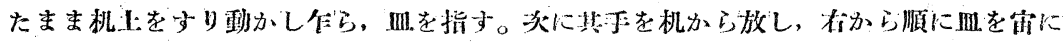

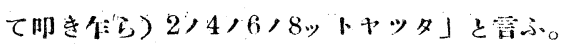

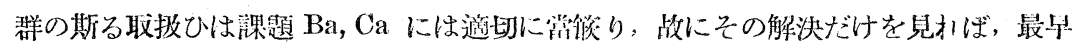

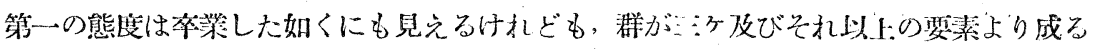

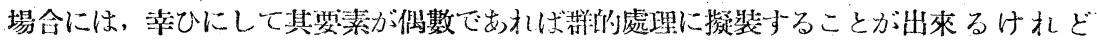

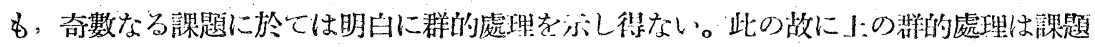

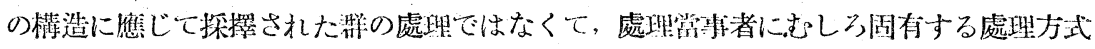

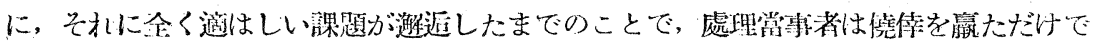

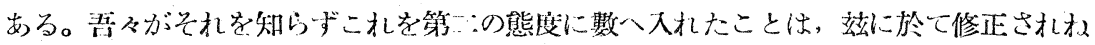
ばならなくなつた。

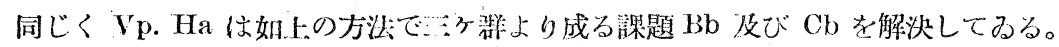

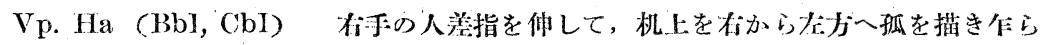

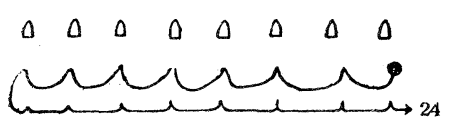
進む。そ水と间時に「2, 4, 6, 8, 10,2,4,6-16」 と留入縝ける。指は矢偯り机上を左から右方一

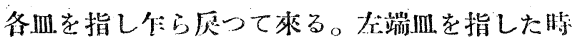

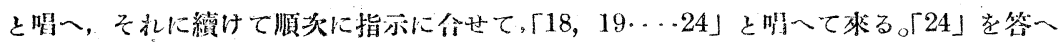

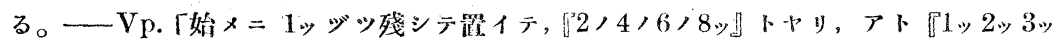

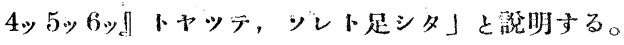

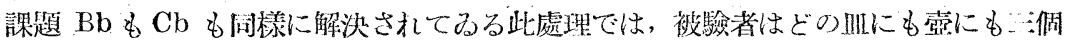
の豆が入つて居り，故に备而の豆の數は相筞しいことを知つてるるが，單にそれだけの 知識では未だ涸宛の群の處理を璂行するまでに到らないで,「2ッと1ッ」宛の群として それを分解的に處理するに止まつた。群の大さを知り其各の大さの相等しさを承虾する

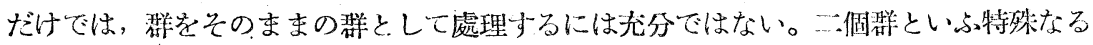

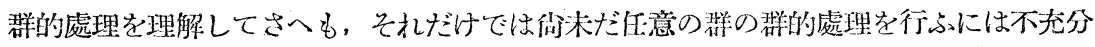

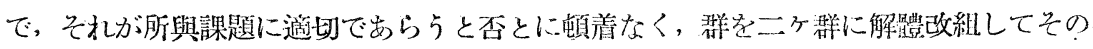
群的處理を强行してしまら。

\section{4. 群を理解せる態度}




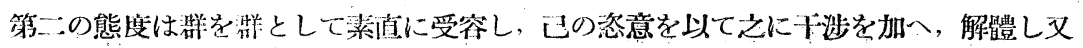
性改組を施すことなしに，與へらるるがままに直接に取扱ひ，それに由つて間接に要素 ○總數を求めて課題を解決才る。第一態度の如く一定の處理方式を固有するのでなく, 所與浲の所與條件を胃屆けてそれに從つて處理方式を隨時適苗に決定し，執はれのない 處理を行ふからこっでは課題性が完全に保た机る。次の例は八ヶ塑を處理する實例で

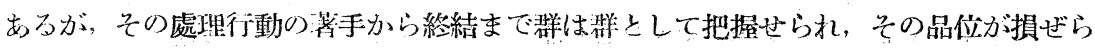
れてるないことを觀るべきでもる。

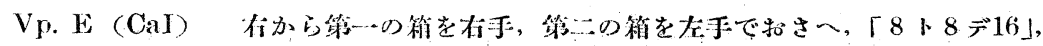

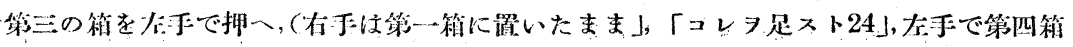

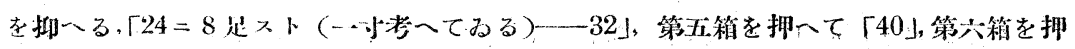

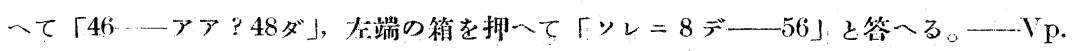
「全部 8 宛是シテ行ツタ」

然し斯樣な處埋のう法は最初から芫成するのではなく, 漸次に成立するものである。

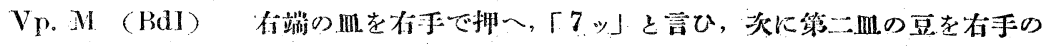
人然指で指ふして，「8ッ9ッ‥14」と數入續ける。稍强い「151の㢣で, 第三血が同

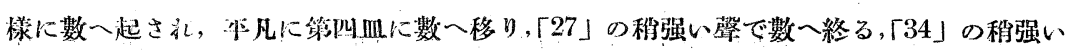

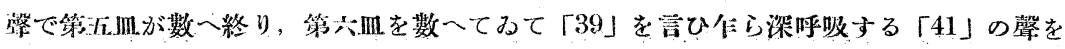
以て第一七IIIL゙數一始むり,「48」の㢣を以て第八四の數へが始むる。54」と答へる。

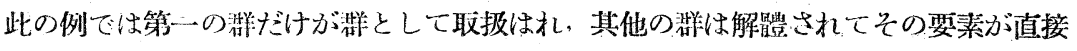

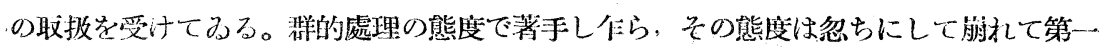

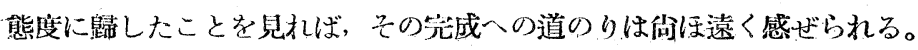

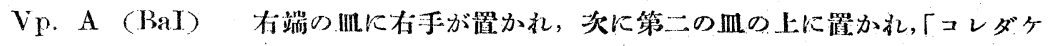

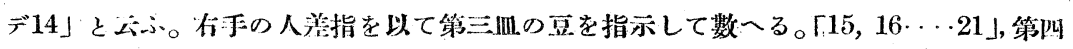

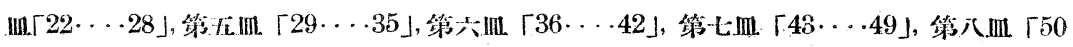
…56」最後の明一は强調されて, そのまま答一とされる。

Vp.A（CdI） 右手の人美指が右端の箱の上に置かれる。指が第一箱の上に移る。 「コレデ16」と公ふ。第三の箱の前にて魟く机上を吅き作ら，右の順序に數へ續け，同栐

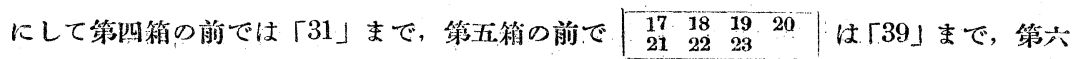
箱「47」, 最後の箱の前では「54」で止み,「54」と签へる。

是等の例では第二の㮅までが群の取报ひを受けて，他の甜はこの恩惠に浴さない。第 二例 (Cd) では箱の不彈の數がその前に再現されてるるから, 被驗者が不彈の數を知り 而もどの箱にも同數でせると知つてるることは疑ひない。此の知り方の點では第一躍, 第二群につ、てと他の羣についてと差別があらう筃はないのに， 何者どの群が第一 


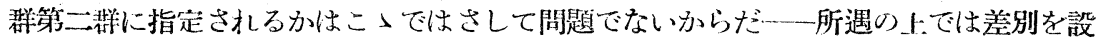

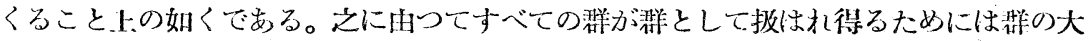

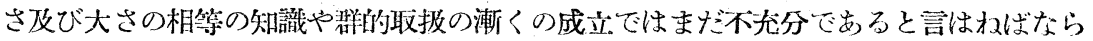
$\$ 20$

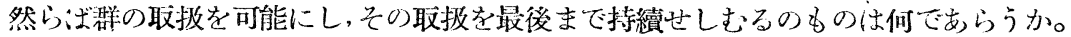

Vp. M (CdI) 右端の箱を右手人美指で指して,「タマハ 8 「と云ふ。手を第二 の箱の前に移し，手首を机につけて同一の場所を輕く印き仨ら,「 $9 \% 10,11,12,13,14$, $15,16,17 」$ 唱へる。「ッン?!——16ダ」手を左少にすつて第三箱を指す,「エェ，ココ デ一ー24」,筙四箱を指しすぐさま,「25，2-」と言ひかけて考へ込む。やがて「32」。第

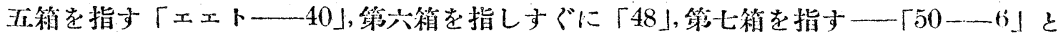

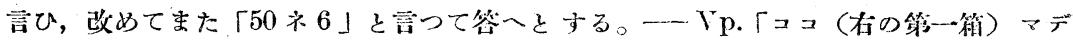
八 8 。レ (第一箱) デ16コレデーエート 24 , コレデ 32 , コレ $71 \%$ 是スト 40 , 又 $1 \%$ 足スト 49 ，ソシテタ $1 \%$ タト 50 エェ50-6」

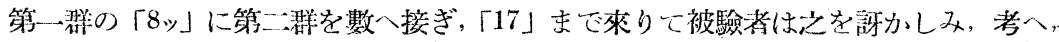

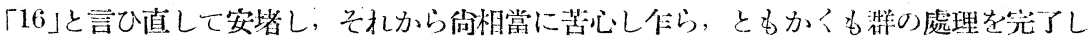

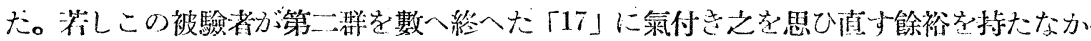

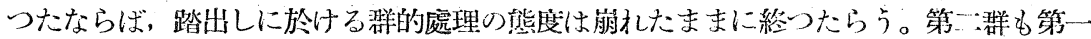

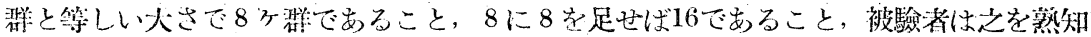

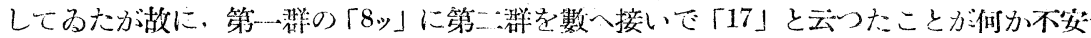

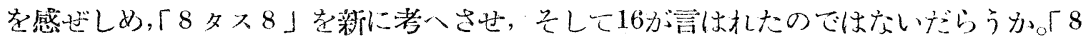

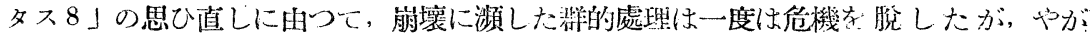
て再び同樣の危難に遭遇する。第二の危機から如何にして伛がれて得たかを推知与ること

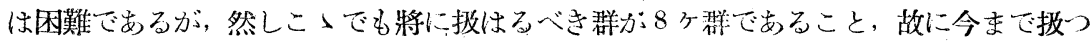

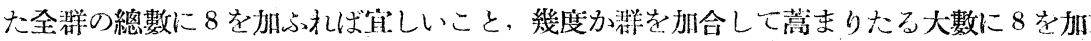
へ能ふこと，8を加へることはそれを一々數へ足すよりも選取すべしと知つてるるこ

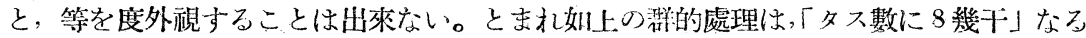
課題の迅速且つ正確なる解決打須つ所が谌ナ゙多大で，此力の充實なることは，原始的 な從つてそれだけ具體的な堅實味の多かるべき數八足す方法の結果に微疑を挿み，突基 に修正を提議し其の修正により多くの信賴を置き得る程でする。故に，臂を群として取

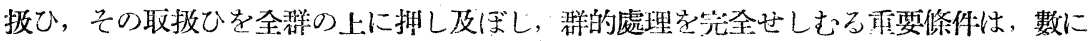
數を加へること，加算力の充實さ一一完成して殆んど Satzの形にまで高められた充實 さでせる。

加算力の充實がこつに至らないならば，整の處理は构めて懓味て，功る解沠結果に 
確信を持つことが出來ない。次の例は之を示してるる。

Vp. Hy （CcI） 何か考へてみる。ウーン!」と云ふ。やがて「2ッデ12- エ ート」腰を少しくヒげ，身體を動かす。「-12ト。アレ? -アレ？—エート?-

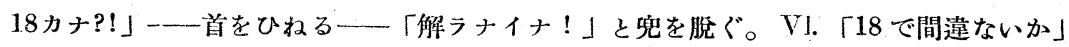
一Vp.「6」と云つて右の箱を右手で蔽ひ，其の姿勢で前上方を見熟めたままでるる。

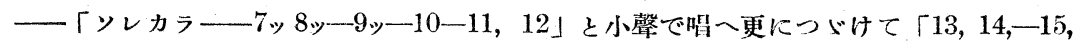
$-16-17,18 \llbracket 18 \rrbracket 」$ 答一る。

極めてたどたどしい解決の道行きにつけ込儿た間違ひないか」と切り达むと，殊勝 と見えた群處理の態度が忽ちにして崩れてしまふのである。

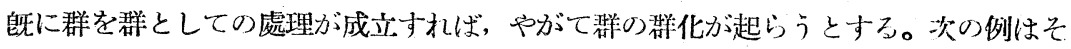
の萠しを示すものである。

Vp. A (CaI) じつと見てなる。一「8ッ」と签へる。一Vp. 有少の三且を人瑟 指と親指とで指して,「コレデ 4 と言ひ, 第三の血を指して「コレデ 6 と云ひ, その 奖勢で,「アト 2 タシテ $8 」$ と答へる。

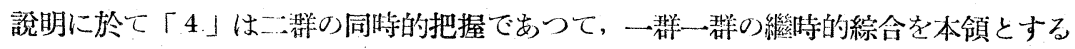
第二の態度からは少しく變容を示してるる。けれども兩四は兩指によつて指六されてる るから，未だ光全なる同時的把捯とは言ひ得ず，ただその萠しを亦すものにすぎない。 最後の䏺が指六さ札ずに處理されてるることも，注目すべさことである。

同じ被瞼者の次の例では, 最初の群 3 個が同時的に把探されてるる。

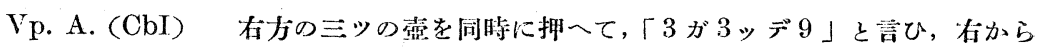

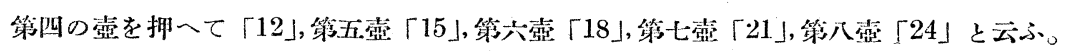

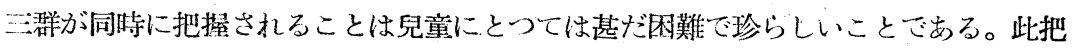
探の方法は第四態度の取报とも謂へるものであるが, 然し此被驗者の此の成功は, 賞て

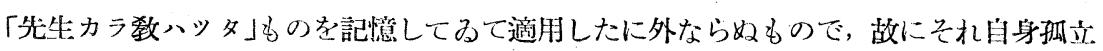
的な特殊なるものであるから，第四の態度からは矢張り區別されるるのである。

\section{5. 群に加工を施す態度}

第三の態度は群の更に深い理解の上に立つ。第二の態度の樣に群を與へられるがまま に處理し, 積極的なる凡ての働きかけを差控へるのではなく, かと云つて, 第一の態度 の樣に狹見なる處理方式に從つて羣に自怨的なる處理を强行するのでもなく，二方に於

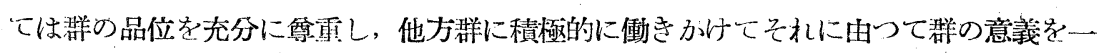
段と高く發揮させやうとするのである。即ち其の處理の仕方は, 與一られた暞の大さが 如何程ですつても, 先づその群と群と二個を以て集團を作り, 次に此の整集團二個を以 てより大なる满集團を作り，更に此のより大なる䑾集團二個を以て更に大なる都集團を 
俳り，かかる遺り方を何處までも續けるもので，謂はば靽の集團化の重疊をその重要な る特芯としてるる。

Vp. M (CbII) 〔19.”0〕10秒にして言ふ。「20ネ〕アレ?!-24」(19秒)—Vp.「始

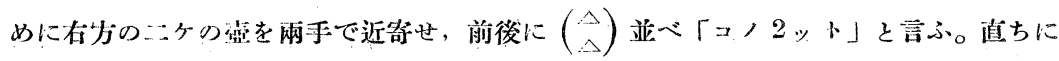

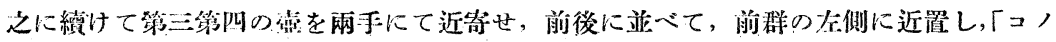

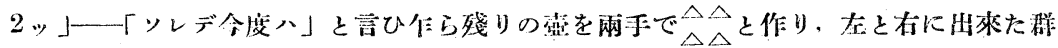

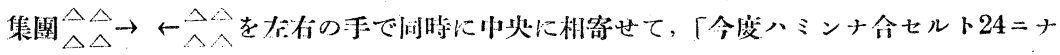
ル」と說明する。

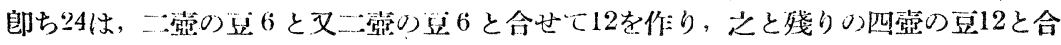
せて 24 として求めら机たのでもる。第・:の態度が徐々に成立して行つた樣にこの態度も 亦徐々にして䒕成する。次の例では第六の群までは集團的に取扱はれるが，最後の群は 路を解いてしまつて解決の力が将僙に達したことをふしてるる。

Vp. Hy (CdII) [2'20.”] 右于で龙少の…箱を同時に抑へて,「コレデ16」と云ひ， 炏の、箱を间時に抑へて「コレデ 16 デ 32 デ一」と言ひ，更に次の-:箱を同時に抑へて 「メコレデ 16 デーーコレデ44デ」と言ひ，最右端の箱を抑へて「コッチタ合セルトー $45,46,47, \cdots 51,52-[52]\rfloor$ 签一る。

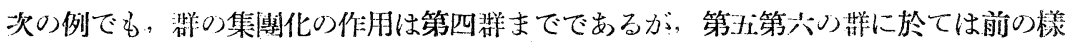
に型を解か叔ばならぬ程には到つてるない。

Vp. Is（AI） 右手と有手とを A A $\mathrm{A}^{\prime}$ に位蜀して「6ト6ト12」と言ひ，左手は OOO-OO

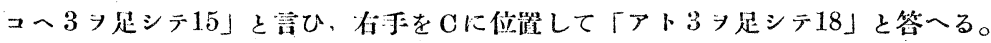

以上の例では，多くの場合に，步を盛りたる四が相互に近付けられて群の集團化が行 はれてるるが，然し集團化は常にかく行はれるのではない。㸪の位置は動かなくとも，

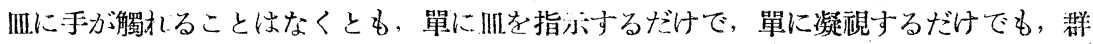
の集漙化は行はれ得る。

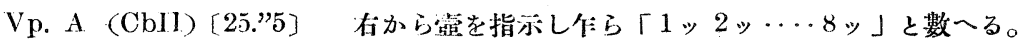
列をジッと見てなる。20秒頃「アレアレ！」と云ふ。「20-4」(25.5秒)-Vp.「右手

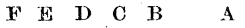

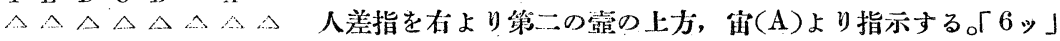

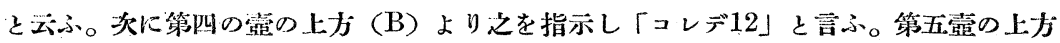
(C)ょり之を示して「15」と言ひ，Dにて「18」，Eょり,「21」，Fより「24」と言つて答 一る。

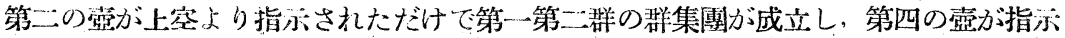

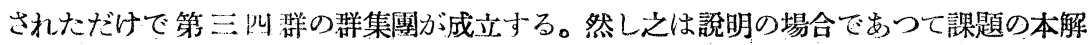


决に於ては㠜視だけで恐らく同樣の處理が行は机たことであらら。かかる處理が甚だ困 蜼なことであることは「アレアレ！」の語によつて推察される。

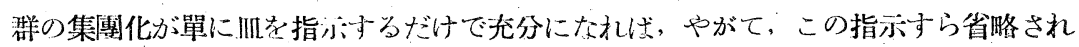
て來る。

Vp. M. (BdII) [50.”2] 存手をAに㨁く,「7ト7トタシテ14」の馨が漏れる。B い Cに置いてみる,「 7 デモッテー-35」と聞完る。Dに置く,「35カラ 7 モッテ來ルト4040-2,42」と聞えて來る。Eに篗く,「42カラ 7 モッテ來ルト一」㢣が途切秃た。やが て「54」と答へる。-DVp.「右から第二の血を在端の皿の前方に $90^{\circ}$ 通して縱列とす

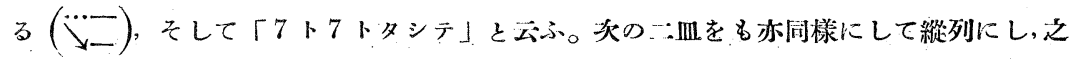
を先の列の去傍に近付ける。そして「マタ之フマゼテ」と言ふ。他の四はそのままにし て言ふ・「アトハ豆习ー・塊りデ勘是シタ」と。

次の例では指を直接に箱に觸孔てるるが，その指小シ第四の箱までで第五箱以後には

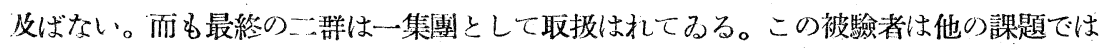
單に指六するだけで同㩐の處理を行つてるる。(上例 Vp. Is 參照)

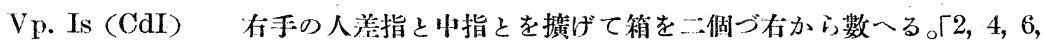
$8 」$ と。そ礼から右の三箱を人差指と指で抑へて,「箱デ16」と云ひ, 兩指を以て第 三箱に輕く觸れ，直ちに第四箱に置かれる。乎のこの運動と別にロでは,「又8タシテ一 24 ニシテ一一四箱デ 32 =シテ」と言ふ。手は第四箱の上にあるまっで,「ッュへ 8 タシテ

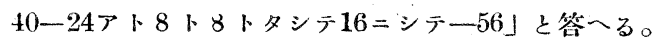

次の例では最後の二個の羣が指示をらけずに處理されてるる。

Vp. Is (BbI) Imを二指でニケづつ指して「 $2,4,6,8 」$ と數へる。「2,4,6,8デミン

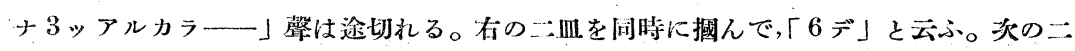
IIIL掝んで「12」と言ひ，次の一血を掝んで「15」と云ふ。手はこの血を掝んだままで, 「アト9デモッテ24」—Vp.「右の二血の間に右手人差指を立てて「6」と言ひ，次の

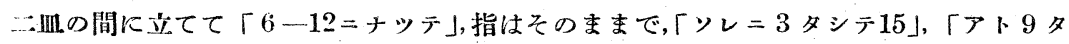
シテ 24 」 VL.「こ扎（最後の三群を指す）は 9 になるか？」-Vp.「6=3タスカラ 9 サ」

以上二例に於ける指分も初の省略は,「アト」詞ち最後に殘つた諸靽の處置に於て見出 され，而してその處理は其等の諸群を集團的に取扱ふことでする。集團化された毞の數 は前例と後例とでは異つてるるが，其の異りは單に表面的で，集團化を動機づける理由 に就いて言へば, 兩者は一に歸するで女らう。 8 ト 8 ト足シテ16」む「 3 が3つで『9』

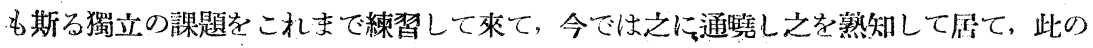




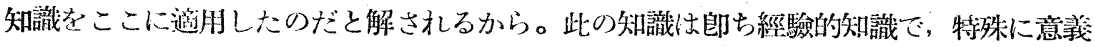
づけられた事態に限つて適用されてるるから，本處理の態度にとつては元來，外來的な る異質的なる知識である。けれども此の適用は課題處理の全過程中にそれの適用可能な る特殊事態が存在しそしてそれが認識されたことを證してるるから, 斯る處理が一段と 進んだものであることは疑ひない。そして上例の被驗者の队省的說明萑見ると第一次皮 第二次の群集團化に指示行動が參加し，爾餘の四群に對しては之が省略されしてるて， そ

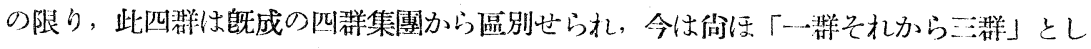
て报はれてるるが，之が一集團として四群集團化を實現することは今一步で女ると知ら

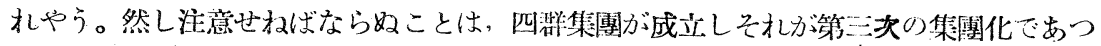

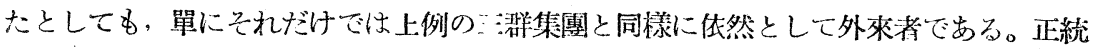

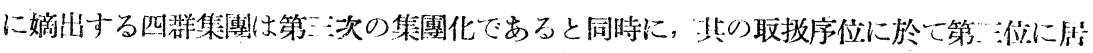

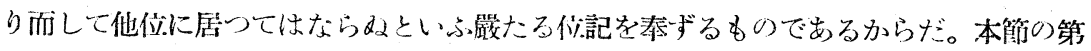
一例は此の事實老明竳する。

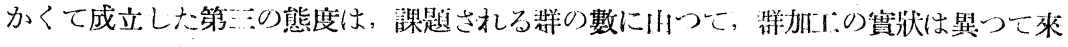

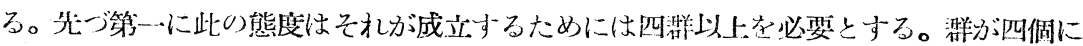
足りない時は，漙の處理がなされたにしても第二の態度との制別は不可能である。此の

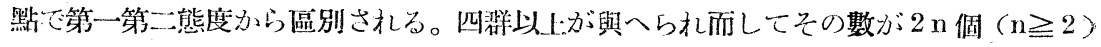

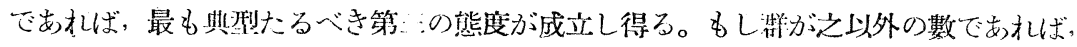
最も手際よく處理されたとしても，2 群の籍型に合致することは出來ない。ここにこの

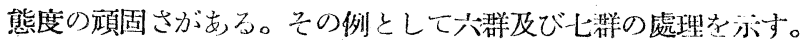

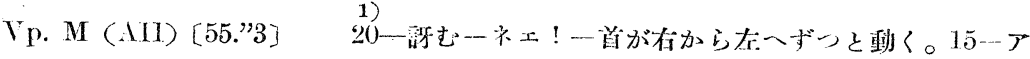

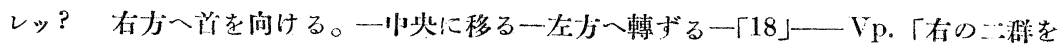

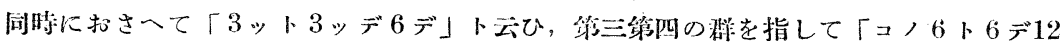

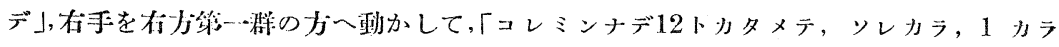
6 モッテ來タ」と說时する。

Vp. Hy (CdII) [43.”3]雨于で頭を抱いて考へてみる。それから右のニ箱を近 寄せて「 8 ト 8 デ16ニシテ罚イテ」と云ひ，次の二箱を网時に抑へて「コッチモ 16 ダか

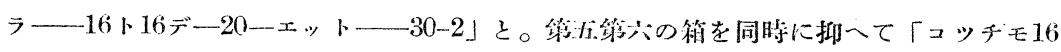

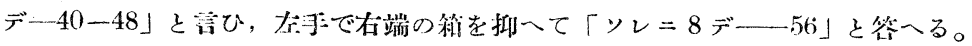

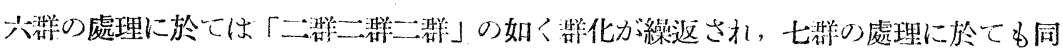

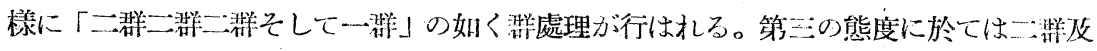

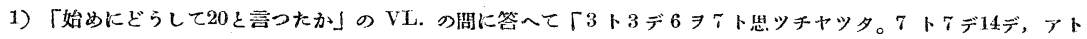

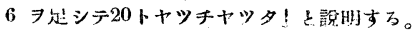




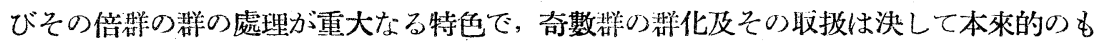

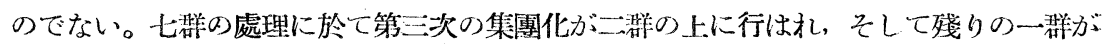
取披はれ、これら三群が一集團を形成することがないのは當然でまる。六群の處理を

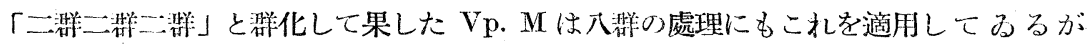

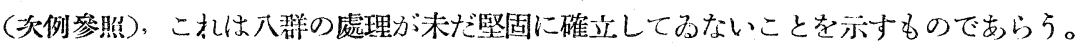

Vp. M (BbII) [42.”5] Aに右手を置き「3ト 3 ト足シテ6」と言ひ，手をBに

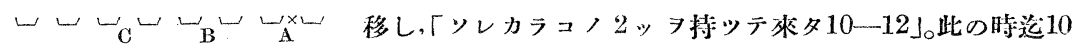
秒經過。手を Cに移す,「ソレカラ $3 \%$ トットタシタノー 18 」。手は C に置いたまま「18 カラアト $3 \%$ 持ッテ來テ 21 」「21カラコク中へ入レテー24」

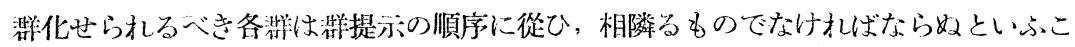
とはない。(次例參照)

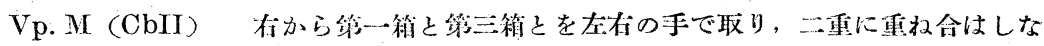

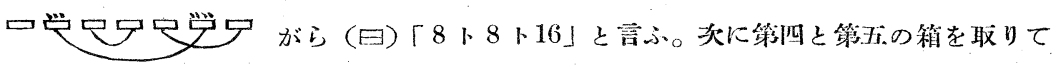

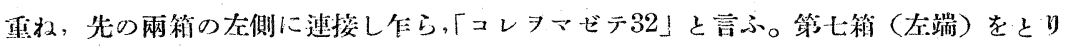

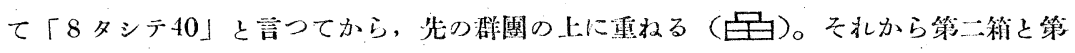

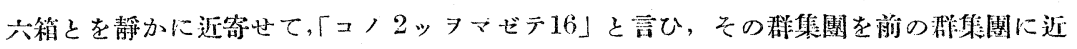
付けること無しに，柳續けて「16ト40トカタメテ56」と言ふ。签一とする。

第二箱と第六箱とは前者は不彈を四個容れし, 後者は五倜入れて, 所與洴の大さの調查

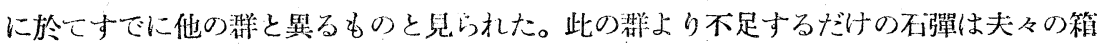
の上に補ひ足され，そしてそのまま處理行動加開始されたから，此一湖は他の染からは

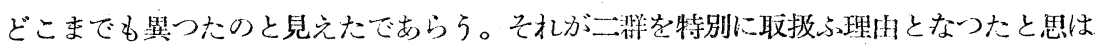
孔る。ともかくも第二洋走越えて第一と第三洋とが一集園を形成したことは大に注目に

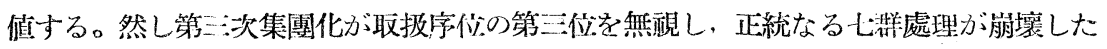
ことが單に上記の如き特殊條件に基づくものか, 或は他の課題條件に由るものかは佮攻 究を要すべき所でまる。

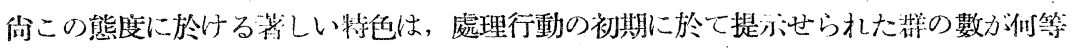

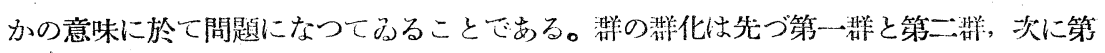
三・第四洋……等と順次に一—この順位は提示の順序に從ふ心必要はないが一一處理せら れて行けば充分だ，所與䁌の數は本來必要ない䈏である。然るに事實はこの數が少から ず間題にされてるる。而してこの例は上に幾度か亦したが以下の例も亦之を示す。

Vp. Is (BdI) 右手の中指と人差指とを以て四を同時に二個づつ指し个ら數一進 む，「2，4，6，8ッ」と。それから右二盒の中央前に兩指を立てる。次に第三策四の四の中 央前に指を立てる。秒はつきりとした小馨で「14ト14ト足シテ28」と言ふ。第五睓を指 


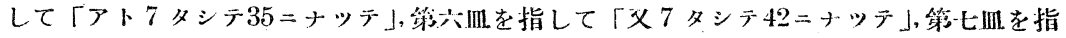
して「メ 7 デ49—アト7タシテ56」とすつて签へとする。

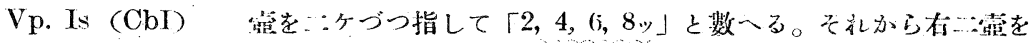

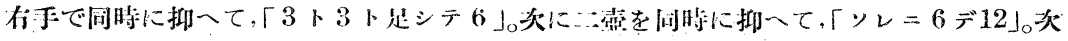

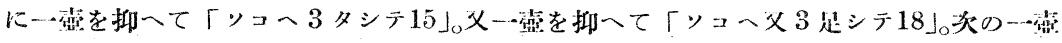

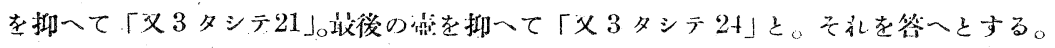

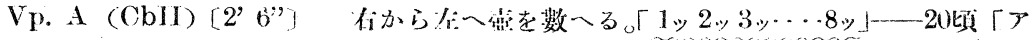

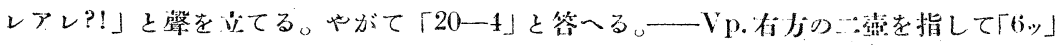

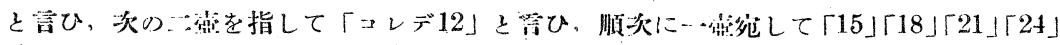
そ進む。

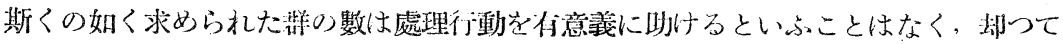

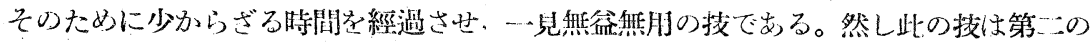
態度に於ては見られざるもので女り, 而して次の第仙の態度でばその處理行動の最初に

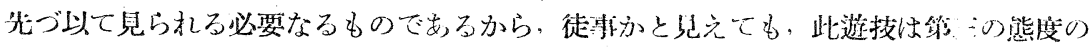
特色とせねばならぬのである。

\section{6. 群を統整する態度}

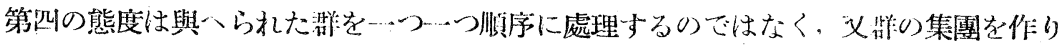

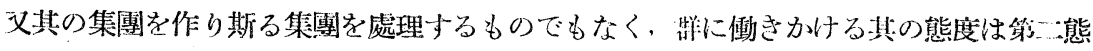

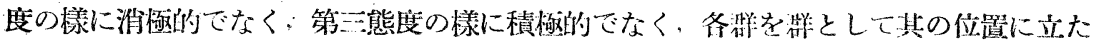

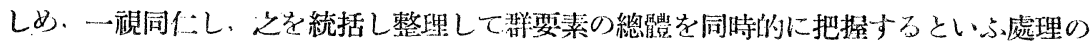
態度である。概括的䜅明を以て云、ばかかる複能なる此の態度むその行動觀察の記錄を

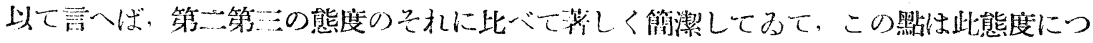
いてて笁以て特記さるべきことでせらう。

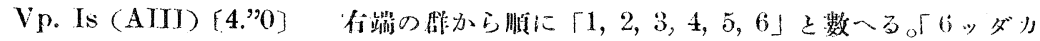
ラネ, 18」.

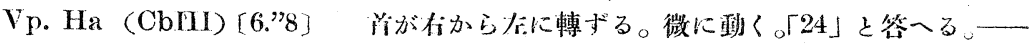

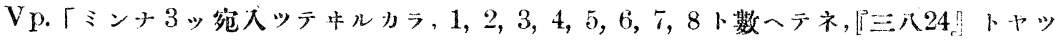
タ.J

Vp. A (CdIII) [5.”2]ジッと見つめてみる。やがて「56」と答へる。—Vp.

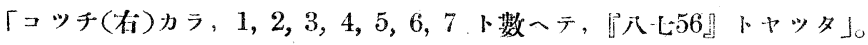

どの記錄む䉮潔である。解決時閔も短い。そして斯る記錄は第一次實驗の場合には見 出されゔ，第三次實驗に於てはその記鉦の殆んど全部を占めてるる。

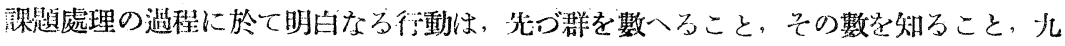


九の馨が唱へられること, そして解答される。然し上記の第一例に於ては九九の撀は唱 へられず, 而も午の行動は圓滑で迅速でその解答は正しい。九九の聲はなくとも明膫に 本態度の處理方法であり, 活も熟練した仕方だと言へるであらう。

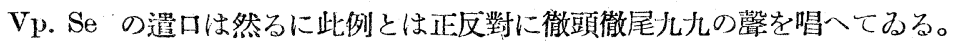
Vp. Se (CAII) 左端の箱を左小指で指す,「八一 8 」と唱一る。其次の箱を指す, 「分二16」と唱へる。第兰箱を指す。分三24」。第四箱を指す,「分四32」。第五箱を右手の 小指で指す,「无。40」。右小指で第六箱を指す,「八六48」。右端の箱を右小指で指す,「八七 $56\rfloor$ と唱一,「56」と签へる。

他の課題の處理に當つては彼は指示行動を省珞し，ただ㠜視線を各装の上に順次に投 じ乍ら,そして後で彼の告白与る所に由れば, その間中或は內浯的に或は微罄を以て九 九の聲を唱へてるる。九九の馨は彼の此の處理にとつては省狢すべからざるものでも る。彼の此の處理は，上三例に見るが如く先以て所與臂を數へ，その數を求める行動を 缺いて居り, 從つて棌要素の總體を直接的に一時に把握することが出來ず, 烊を一つ一 つ順次に處理して最後に漸く要素の總體を把握するのでもる。彼の群處理は斯く繼時的 であるが故に，九九の馨こそ唱へては居れ，本質的には第二の處理態度と少しも選ぶ所 がない。さればこれは第三の態度以前に於て述べらるべきであつたが，殊更に本節に持 来つたのは九九の馨が用るられてるるためであり, 斯る用る方が正統なる九九使肘と相 違すること袁指摘し, 如何なる九九的處理むすべて高き段階の處理でせると解する考へ に反省の機會を提供せんためである。

さて本態度に於ても初學者の゙兀九の技ひはVp. Se の場合と酷似してるる。

Vp. Ha (CaII) [10."6]「18」と正答する。一Vp.「6ッッ゙ッ入ッテキルカラ，

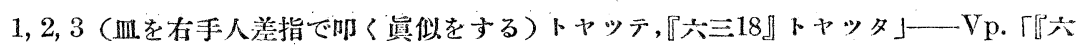
一 6 , 六二12, 六三18』トヤッタ」。

然しかかる類似子實は表面的のことである。Vp. Se に於ては, 課題處理は九九の 警を以て始り先の系列を迎りそ扎と共に終るもので, 九九系列は處理過程の全體に亘

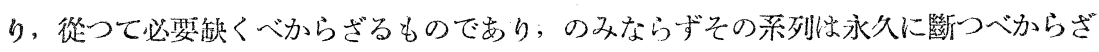

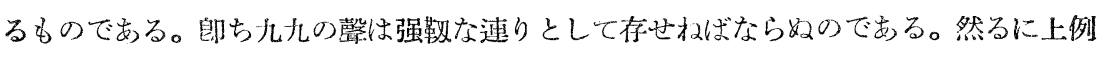
に於ての九九侹用の意義は大いに異つてるる。先づ第一に其の處理過䠋は, 群の大さを 調べ䬺の數を調べる行動を以て開始する。九九使朋は, 斯る行動からの必然的繼起者と して意義付けら扎處理を一舉に完了することを使命としてるる。故にその所作は最も簡 絜にして最も俊敏神速的でならけばならない。にも拘らず上例の九九使用は系列を迎り て一見て長に流れたと思はれるが，之は初心者の立場としてきもを得ざるに出でたこと である。元來此の九九系列は被驗者の胸中深く秘められてるたものを, 實驗者の鍵鍢が 
之を披顯したのである。もととは，隱痏を目的とした秘藏ではなく，殊更に表明の必

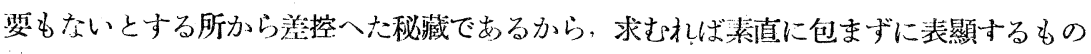

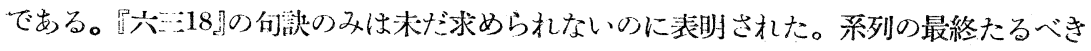

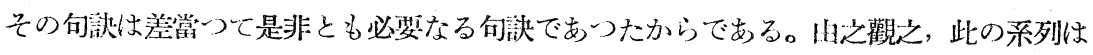
…種の句弱を以て一聯を成し，外部への表明を要しない部分とそれ在要する部分と，か く分節的に構造づけられたものである。Vp.Se の九九采列には斯る構浩的分化が見ら

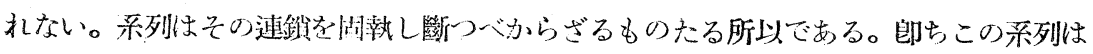
必須なる系列に゙るのに對し、か心系列は假借なる系列であつて, 肉者はかくの如く暴 つてるる。

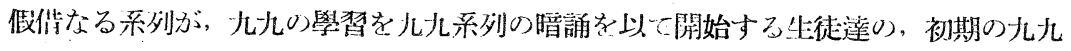

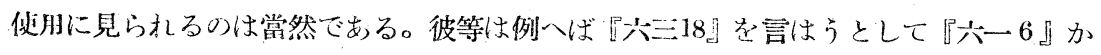

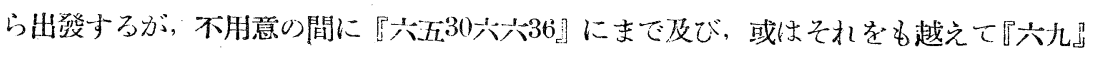

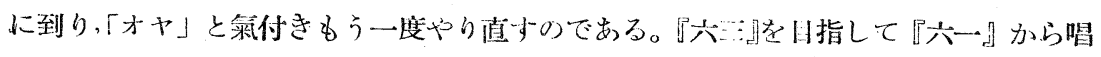
一起し, 確かに『六三18』で修上し爾餘の句訣を顧みない程になることは大いなる上達

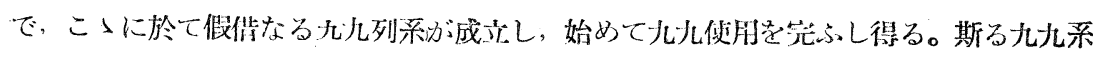
列は補助的部分と本貲的部分とに分節し，左圖の如き構造を成してるる。馭ち補助的部

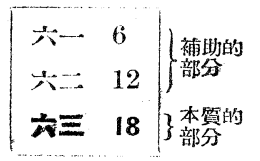
分は內亩的で外部入の表明を要求されないが，本質的部分は强く 外部への表明を要求せられ，時には單に特に强調せられるだけで あるがどこまでも外顯的傾问圭持つてるる。補助的部分は漸次 省略さ扎て系列は漸次に簡約される。補助的部分が全く不要として畗却されるに到つて 虽立なる九九の句款が成立する。而して第㞦態度の處理過程にその一成員として參加 する儿九使用に於てかかる獨立なる句訣が㜆用されるに到つた時に，第四の態度は完成 されたと云へるのでする。然し斯る䒕成の域に於て子仯多少の發達は存する。（次例參 㸃)

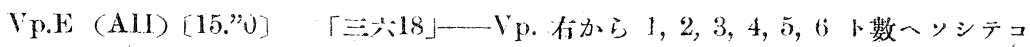
レ (存端群) $71,2,3$ ト數一テ 『三六18』トトッタ」

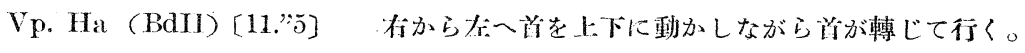

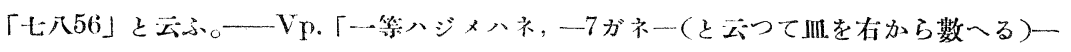
$8 \%$ アルラネ, 七八56トャッタ」

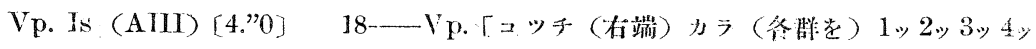
$5 \% 6 ッ$ ト數へテ来デ,6ッアッタカラネ, 18」

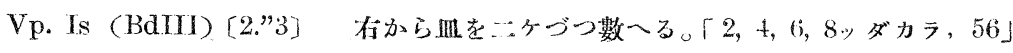
- Vp. 
此等の解決行動は立派に第四の態度でその解答はすべて正解でする。然し前二例では 解決時間が長い。加之, 其の解答は九九の句訣を以てしてるる。その队省的說明的行動 に於ても, Vp. E は群の大さ再調查して居り, Vp. Ha は群の數を數一直してるる。 是等の點は全く後二例と相晎してるる。

說明的行動と本格の解決行動と赾全く同一と視ることは出來なからうが，然しそ机を 全く同一でないとすることは不可能である。寧ろ兩者の間には緊密なる一傚があるとす るのが最も自然であるから,この點よりして, 前二例と後二例との間には解決過程に相 異があると考へねばならない。而して此の相異によつて, 前二例では解決時間及び解答 の仕方を異にしてるる事實が理由づけられる。Vp. Is の解答では儿儿句計は必ず唱一 られるといら要はない。よしその必要があつたとしても彼の朋る力は前二例の被驗者の

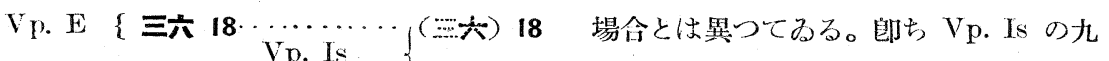
Vp. Ha\{ 七八 $56 \ldots \ldots \ldots . .$. 七八 56 九句就は强調部分と弱調部分とを以て明

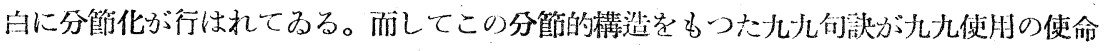

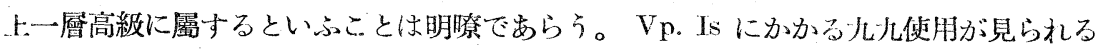
のも彼は彼等のクラスで斷然頭触表してるるものでむると知るならば，以上の事實が 決して偶然でないこと它了解し得よう。

\section{V. 理 論的追 究}

\section{四種の態度に於ける數操作}

相を處理する以上四種の態度に於ける數操作を考察しよう。

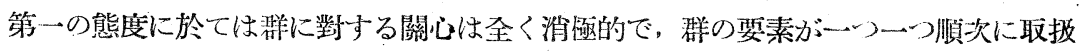
は礼, それと同時に之れに一對一の對應を保ち乍ら, 數詞采列が造られる。要素の报方 は直接的には手指を觸れ或は指差し或は頭首を動かし凝䅐を以てするなど, 開接的には 机を輕く吒き首を動かし指を折るなど，具體的行動は一樣ではないが，要素を一々指亦 してみる點ではすべて同理である。かかる數操作は「數へる」といふ。

二㗑を一時に指示し, 之と對應して數詞系列をその偶數系列だけ順に巡る仕方があ る。これは確かに群の报ひちで二個群の課題にはらさはしい處理方法であるが，圠よ り大なる群の扱ひには適切でない。然し往々にして此の不遮法は强行されて, 故に此方 法㤝固な性質を有してるる。

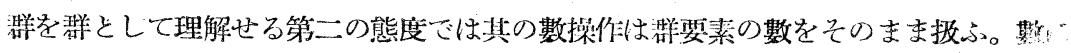
又數を添增することを「加へる」といふ。故に數をそのまま报ら第二の態度の數操作は 「加へる」ことである。然し「加へる」では二項が與へられるのが本來であるから，多 数の項を有する吾々の課題の解決に於ては特殊なる「加一る」が行はれる。郎ち「加 
る」ことが累次に反復される。之を通常「累加する」と云う。累加に於ては, 單に, 多 項であることを條件とするだけで項の性質は問はない。吾々の課題では各項は相等しき 大さを有して居るから, 累加の中の特殊なるものとなる。郎ち第一態度に於ける數操作 は特殊なる「加入る」の筒特殊なるものであると云へる。

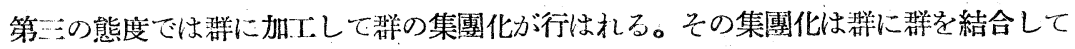
二群集團を作り，之に他の二群集團を結合して四群集團を作り，次に八群集團を作り・

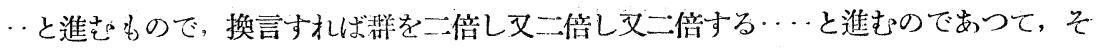
の結果, 溯要素の數は二倍され又二倍されい...て增大して行く。然しこの二倍の仕方は 一の數にそれと等しき數を作つて此の相等しき兩數を加合するのだむるから, 此數操作 は「倍加与る」と名付て宜しからう。

第四の態度では先づ群を一つ一つ數へてその數を求める。豫備課題で群の大さ及び各 群の大さの等しいことは承知されてるるから, とこで群の數と群の大さ郎ち群要素の數 と, 此の二數の上に九九使用といふ謂はば一種の機珹的施術を適为して, 二數に對する 第三數を郎座に織出し，之を以て要素の總數之理解する。群要素の總數を一擧に把挃す ることが著しい特色で，それは主として九九使用の功でするから，此數操作は通俗には 「九九（操作)」とされも言はれるが，「脚ける」「乘ずる」と呼がのが普通である。

以上四樣の數操作を夫々の數操作に於ける指分行動の上から比べて見よう。

「數へる」に於ては指示行動は群の要素在逐一に指亦して所與群の全體に行き亘る。 故にその手數は實に夥しく且つ繁細を極めてるる。斯る指示行動に對應してるる數詞系 列の巡り樣も系列順序に從つて飛躍なく進むのであるから, 其の速さも緩漫である。謂 はば一步一步と地步を蕉めるのであるから原始的な此の進行は堅實な行き方には相違な いが，身體部分を勞することが多い所からやがて物5さや痩れさへむ覺えしめられるの でもらう, 此の數操作に熟練するにつれて對象への解接が單に指差しへ凝視へと，そし て直接的指示から間接的指示へと淮んで行く。對象を間接的に指示し得る程に進めば, 二ケ群を二指にて又は一指にて同時に指六し得るに到り, それと共に數詞系列の辿り樣 む偶數だけ逐ふ樣になり, 少しく跳躍的進行を示して來る。

「加へる」の數操作は群から群に指分を移し幦每に休止し群の指示は一觸, 一指, 或は 一瞥を以て足れりとするから，指示行動はその手數を大いに省いて甚だ簡單になる。此の 行動と共に群要素の把握數は群の大さだけ順次に墂大するが，もはや數詞系列を辿ると いふ意識は薄らいで, 數の霄大だげが前景に出てるる。順次の數の增大量はその時の課

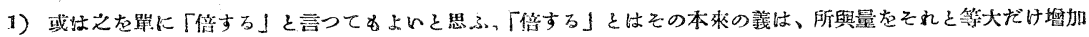
することであるから。四六倍制、實物の倍大などと用るられる。外國語ではそた doubling and addition と か Verdoppelung und Addition と云ふ。數學史では、この方法がエジプトに於て最む進んだ算法として普 通に用るられた所からエジプト法と言つてるる。 
題の條件に從つて變り一定でないが，指示行動はそれに何等の拘束をも感じないから： 此數操作には課題に對して頑固な不自然な態度が少しもない。

「倍する」の數操作では無休止なる連續的なる指示行動が發現し，それに由つて帮の集 團が同時的に指示される。かかる群集團は操作の進行と共に漸次に擴大し，その擴大は 愈々促進されるから, それと共に群要素の數も次第に督大しその霄大は幾何級數的であ る。然しこの增大も彼の撗大も段階的で，それは指示行動の休止に上つて生ずるのであ る。即ち此數操作に於ては指示行動は無休止的なる連續的なる指示行動の休止と繼續と を以て所與羣の全體に働き及ぶ。

然るに第四の數操作に於てはこの矛盾が解消される。即ら無休止的なる連續的なる指 示行動は休止なく自由に活潑に働いて所與群の端から端に到り, それによつて全群の群 要素の總數が全く同時的に把握されるのである。

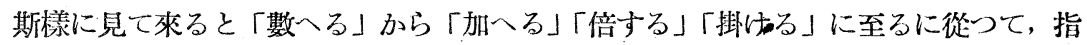
示行動は次第にそれ自身の力量を霄し來り, 其の力動性の展閉し來る實狀がまざまざと 見える。最初の頃は群要素の一々を安息所として休み优みの進行であつたが，一時的行 程を擴大し安息の地處を先方へ移しやりつつ隻行し得る樣になり, 遂には無休止なる進 行を以て一躍に目的地點への飛翔を實現する。指示行動の斯る發達段階の差異をその行 動の休止點を以て圖式的に示すならば, 下に示寸如くで, 數操作が I からII, IIからIII,

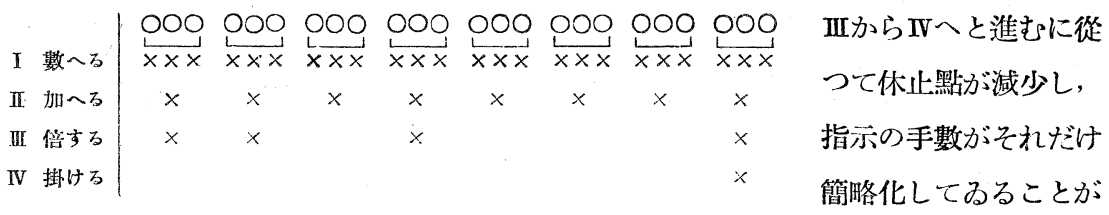
明膫である。起點から出て終點への到達を出來るだけ速かならんと希望する者には，I の道行は如何にも不便であり, INの道行は最も便利であると直觀されやう。かくして 「加へる」ことは「數へる」よりも,「偣する」ことは「加へる」ことよりも，そして「掛 ける」ことは「倍寸る」ことよりも又他の何れよりも簡便なる方法であると言へるであ らう。そしてこつに於て、「乘法は加法の簡便法だ」゙といふことの意義が明白になつた。 然し同時にこの言說の如何に不徽底であることか。「掛ける」ことと「加へる」こととは その方法に於て全く異つてるる。一般に「加へる」ことのその特殊なる，そして又特殊 なる吾々の「加へる」ですら,「脚ける」こととは異るのである。してみれば「乘法は特 殊なる加法である」との言說がまた如何に不橵底なるのであるかが明膫する。乘法は加 法から嚴に區別されねばならない。

\section{乘法行動の成立}

乘法を與へられた群全體の群要素の總數を同時的に把握する方法であるとするなら 
ば，斯る同時的把握行動は如何にして成立し何に由つて支持されるのであらうか。而し てそれを追究し解明するためには，乘法行動を特に顯著に特色づけてるるところの無休 止的連續的指示行動の由つて來るところを究明す机ばよいであらう。

指示行動の最も原始的なるものは，事物に直接に觸接する行動である。此の觸接は事 物に唯一度だけ觸接することを必要條件とし，一度も触接されず一度以上觸接すること は共に許されない。故に觸接すべき事物と，最早觸接すべからざる事物と兩者をはつき りと見分け，その分別を決して誤らないことが重大である。郎ち此の指示行動は「見分 ける」の上に立ち，これに支持さ机てるる。此の事實は一般に高級なる指示行動に見て も事實である。

第一態度の數操作こは所與群からその要素だけが見出され，それを單個と見それを數 八る。要素は此の郡彼の群として與へられてるるにも拘らず, 澼と裙との間には見境が 無く，㖓の分机分机を無視してそその要素だけを看取する。郎ち群を見分ける力弱く群の 桉素だけを見分けるが故に，群の要素が指示されるのである。

第一の態度の數操作に於こは，見ることは备都の上に及び，洋每に停止し，與へら机

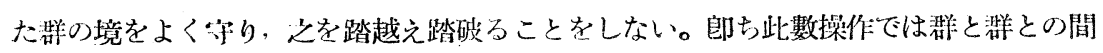
に見境がはつきりと置か扎，此の蒋の見分けに山つて群岛に指六する行動が成立する。

第三の態度の數操作では，女とより各靽が所與條件に從つて見分けられてるる外に，

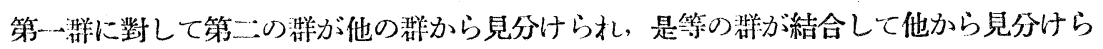
れ，次に此荈集團に對して第三第四の羣の群集團が見分けられ, 兩群集團が結合して一 集團を成し爾餘の郘から見分けられる。かく群の集團が見分けられ，その境々に指亦行 動は休止する。

指示行動は斯くり如く見分ける作用に由つて支一られ, 又これは確かに指亦行動に助 けられ，兩者は實は二にして一なる働きの表裏を成するのの㨾である。然らば指示行動 が無休止的連續的に働いてるる第四の態度では，見分ける作用は如何なる狀態にあるだ ら5

第一態度の見分ける働きは既に分秃分れしにある要素郎も個を他の個から見分けるので あるが，第二の態度の見分ける働きは，個の集合を與へられた通りに境してその緾りを 見分けるのである。故に個は少しも見失はれてはるないで, 必要なれば何時でも自由に 數へ得る如く見分けられてるる。第三の態度の見分ける働きは, 個の緾りの更に緾りを 見分けるのである。緾りが二重になつて居り，そして第二次の緾りは與へられたままの むのではない。一次的な個の纊りを一の個と見作し單個として扱つて數へ求めたもので ある。郎ち二次的な縓りは與一られた一次的な緾りを個に作り, 然る後作りむげた縓り 巨゙ある。緾りを內に作ると共に外に作り，內を分つと共に外をも分つたのである。第三 
の見分ける働きでは分つことが斯樣に强調せられ，課題された分ちを受動的に看取する 第一及び第一態度の見分ける働きと暴つて，むつと能動的な發動的な力强さを有して るる。相違はか程に明瞭であるから，第三の見分けるは「見分ける」と記して區別する ことが必要であらち。「見分ける」0働きに支持されたる指亦行動それか無休止連續的指 ホ行動である。而して乘法行動は此の指示行動に明つて特色づけられてるるのであるか ら，それはまた「見分ける」作用に基礎ゔけられてるると言八るので女る。

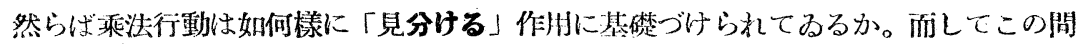
に解答するたやに第三の態度の特色たる集團形成を, 重復の嫌ひは多るが, 再檢討せね ばならない。第三の態度の成立に於ては群は四群以上與へられて居なければならないと

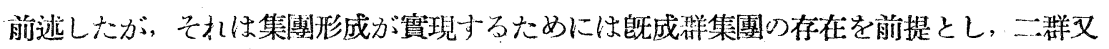

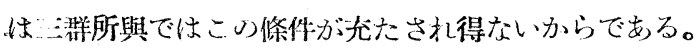

相等しき群ABCDE…が與一られ、AとBとが先づ結合して…集團を作り, 既 (A) (C) (D) 成集團として資格つけられる所から集團形成は歷然として來る。A

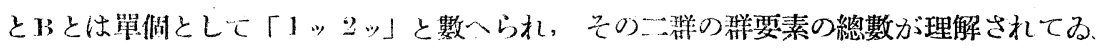

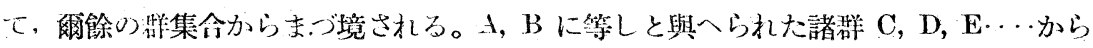

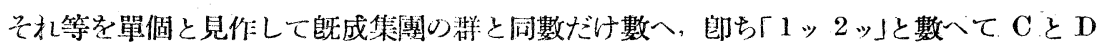

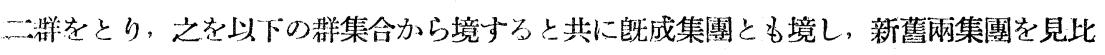
ベ, 新集團の洋䒚素は既成集團の群要素に等しと理解する所から, 直ちに此の總數を以 て被の總數と把据し，此の等しき网總數を加合して第: : の總數を把提し，之によつて

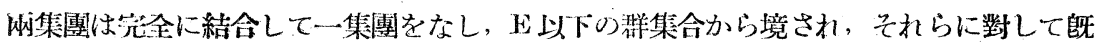
成集團としてつ地位に立つ。集團形成はこつに一先つ結了する。

境する働き即ち「見分ける」作用は，こ〉に於ては等しき諸群を等しく作り等しから しめ，そして等しと理解し等しきを把る作用で,「見分ける」と「等しくする」とは一如 の作用として働いてるる。勿論嚴密に言へば，その活動範圍には相異はむらうが，その 大部分の範圍に於て「見分ける」作用は「等しくする」作用として働いてるる。等しく する」作用は二つの方向に作用する。（1）等しと與へられた群を等しと見分け，とれを 等しき單個と見作し，之を數へて群の數を決定する。(2)この群の數が既成集團の群の 數と相等しと見分けて, 溂集團の群要素の總數は既成集團の群要素の總數に等しと理解

1）各數操作に一於けっ「見分ける」の作用た四示するなら次次の策けなる。

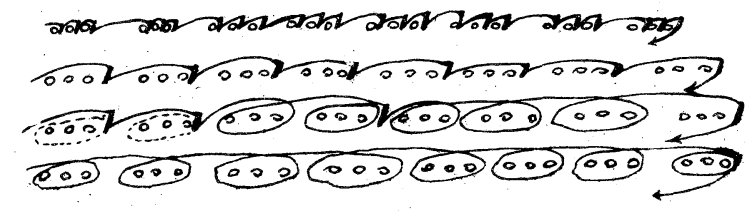


し, 之を把る。郎ち「等しくする」作用は既成集團と等しく䉼集團を作ることであり， それは既成集團の構造を見分け，それと見比べ作ら，それと相等なる新集團を作るので ある。郎ち「等しくする」作用はその重要な部分に於て「見比べる」働きを極めて明白 に行つてるる。「見比べる」作用は最早「等しくする」作用ではない。け机どすそれはこ 孔から別に作用してるるのでなく、等しくする」作用中にそれと必然的聯關に於て作用: ナるもので女る。「見比べる」作用は「見分ける」作用と別に作用するものではない,實 にそれは「見分ける」作用の上に立つて行は扎得るむのでせる。か樣にして「見分ける」 ことと「等しくする」ことと「見比べる」こととは，別別三種の作用ではなく，三者は 一態の作用態として必然的聯舶を以て進行するものであり，それによつて集團形成とい ふ行動が實現するのである。

集團形成が既成集團の存在を前提とするれけは，既成集團が「見比べる」作用を通し て集團形成に參與与るものだからである。郎ち既成集團は「見比べる」作用に由つて一 の敂形と資格つけられ，集團形成の行動を誘起し，之を指導し促淮し已の力量一杯の助 力を以て先達としての責を完うする。己の力量を越えての助力は不可能である。第三の 態度に於ける數操作の出發に於ては, 既成なる街集團は與へられて居らず，第二の態度

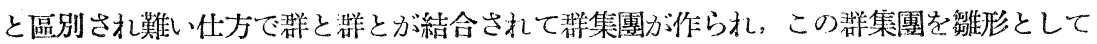

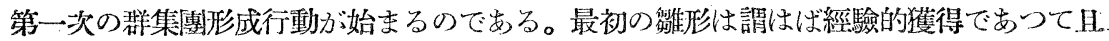
最小の羣集團でありそとして之と見比べて作られる第一次の新集團は故に最小なるも のである。新舊兩集團は結合して第三の集團を形成し, 之が第二次集團形成の雊形とな り，前よりも一段と有力なる指導を行ふっのである。かくして集團形成は谷々活潑とな り, 既成集圍は更に擴大し更に有力になつて，集團形成の行動は不斷に發展的となる。 次第に有勢を加へる集團形成行動は休止的だ，その一々の行動は開始と共に總息を有し かかる行動が反復されるのである。其の行動の休止は穊成集團の力量に限界があるから であるが，その行動の不斷の向上的有意義的の反復練習によつて，兓成集團の力量が夼 實されるに至ればやがて無拘束的な活動自由なる集團形成が成立するに到る。この成立 が郎ち第四の態度の㳯處理である。

既成集團はその成員として一定數の相を有し，これらの羣はすべて相等しき數の洋要

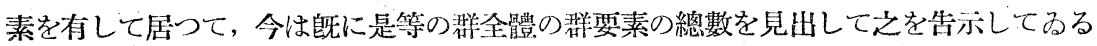

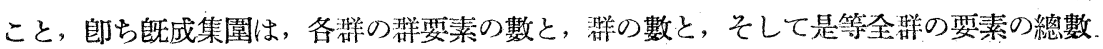
とこれら藪を揭示するものとして，或は是等三數間の關係或立を覽示するものとして 雛形たり得るのであり，集團形成はかかる關係成立の垂示に由つて蔌集團を作り上げる のである。然し乍ら此關係成立は吾々の場合では，豆と而とに由つて支持されて居り， かかる具象的支持を必要とするが故に，此の篗形はその力量に限界を有し，その活動が 


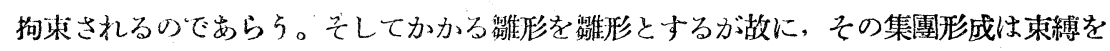
受け，休止を象が扎得ないのであらう。維形がその具象性を脫却して自らを純化し，そ の覽方洔る關係成立が抽像的に保持せられ, かかる雛形の多數が論理的に整頓され組織

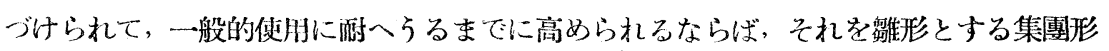
成はその行動在製时されず自内な活動を營みうるに到るであらう。是机郎ら乘法行動の 成立である。

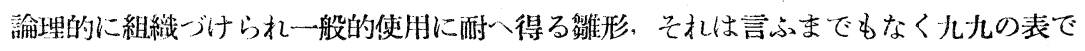
ある。乘法行動炕實に此の九九の表に由つて指導される。即ち此の行動は與人られた泮

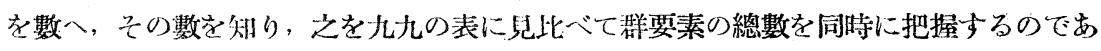
る。見比べの作朋は先つ始めに課題の構造を見分け, 等しと與へられた群を等しと見分 计, 各群を等しく哩個と見作して, 是等を無休止連續的指六行動に由つて一統に數一, 其の數を見出し，然る後九九の表に見比べるのである。勿論吾々の被驗者は九九の表を

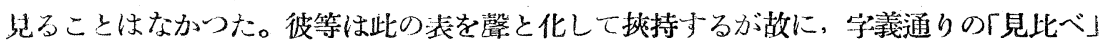
の作川はしなくとも決して之を省略してはるない。然し作ら單なる見此べの作用は賁の 乘法行動たり得ない。「見分ける」作用に由つて基礎づけら机, その作用の必然的の繼起 者としての墢展者としての「見比べ」の作用，かかる「見比べ」の行動が乘法行動たり 得るのである。

(1936年: 3 H 25月原稿受附) 
(Zwar japanische Buchstaben verschieden von europäische Buchstaben sind, aber als wohjgelernte Zeichen von Gegenstände diese beiden nicht verschiedene.) (Siehe Versuch I, Fig. I, S. 147)

(3) Durch Modifikation der Farbensorten (um diesen individuellen Unterschied zu prüfen) können wir folgende allgemeine Tendenz anerkennen. Wenn es wenige Farbensorten in der benennenden Farben-Tafel und Farbennamen-Liste geben, ist die Benennungszeit kürzer als Lesezeit von Farbennamen. Und je mehrere Farbensorten, desto länger wird die Benennungszeit als Lesezeit. (Siehe Versuch II, III, Tabelle I, II, Fig. II; III, S. 150, 152)

(4) Lesen von Ziffərn (1, 2, 3) als Zeichen für Farben (rot, gelb, blau) wird durch einige Einübung schneller als Benennen von Farben. (Versuch I)

Dies hat Heymans schon in seiner Versuch gezeigt.

Lesezeit von Ziffern als Zeichen für Sinnloswörter KAN RON BUN ist auch kürzer als Lesezeit von Farben als Zeichen für diejenigen. (Siehe Versuch IV, Tabelle III, S. 153)

Ich vermute, solche Tatsache nicht auf optische Deutlichkeit von Ziffern beruht, sondern auf innere komplizierte Situation; genau haben die Ziffern als assozierende oder zulesende Gegenstände die festere Ordnungs-Tendenz. (Siehe Versuch V, Tabelle IV, S. 155)

(5) Zwischen der Benennungszeiten von Figuren $(O \Delta \square \circ$ is $\diamond)$ und Lesezeit von Figurennamen (丸 Kreis, 三角 Dreieck, 四角 Quadrat, 棈蒷 Ellipse, 星 Stern, 菱 Laute) gibt es oben (3) erwähnte zeitliche Beziehung. (Siehe Versuch VI, Tebelle V, Fig. IV, S. 156)

(6) Unsere Versuchsergebnisse mit Koffkascher Namen- und Zeichen-Funktion $z u$ erläutern scheint mir nicht passend. Sondern sie müssen auf die zusammengesetzte innere Umstände beruhen. Es bedarf noch weitere Versuche um die psychologisch adäquatere Erläuterung zu ausführen.

\section{(From the Psychological Institute, Tolyo Imperial, University)}

\section{A Study on the Process of the Multiplication}

by

\section{H. MATSUMOTO}

The multiplication is said to be the progressive calculation of the second stage and to develop from the addition which is the progressive calculation of the first stage. What is the process of this development? In what points are they different from each other? As to these questions the following formula $(m)$
$a+a+a+\ldots .+(2)$ 
nothing. This article intends to pursue the reasons why many $a$ in the left side can be represented by one $a$ in the right, why the parenthesized $m$ becomes to be able to rank with the $a$, and why the plus signs change into a multiplication sign, etc.

The subjects were 15 boys of 7-8 years old. A certain number of dishes, each of which contained several baans, were presented to the subjects and they were asked to tell the total number of beans. The procedure of getting the results was freely left to the subjects, and their behaviours were very carefully observed and recorded. The experiment was repeated four times for the same subject and the results were compared.

Four types were classified of the behaviours, which the subjects showed when they dealt with these groups of beans.

I-Type: The subjects were indifferent to the groups. Each element of the group was perceived separately and directly pointed at one by one. One to one corresponding to this action of pointing, the series of number words were uttered and at last the total number was announced. This method of operation may. be called counting.

U-Type: Each group was noticed and pointed as such one by one. The number of elements of each group was added at a time and at last the total sum was acquired. This operation is called adding.

IUr-Type: The grouping of two groups, one of which being equated to the other, was a chief characteristic of this type. The number of groups pointed at one time increased geometrically, for instance, at first one, then 2 , then 4 . So the number which was acquired increased by two fold at every time. This operation may be called doubling, or doubling and adding.

IV-Type: In the first place all the groups were counted and the number of them was found. Then the total number of elements of all groups was produced at once by the help of the multiplication-table. This operation is called multiplying.

These four types of behaviours are related to each other genetically and the I-Type transforms into the II-Type and the II-Type into the III and so on. (See Tab. 12 in the Japanese Text p. 173) From this fact we can conclude that adding develops from counting, doubling from adding and multiplying from doubling. The first three of these operations are successive methods and the last the simultaneous.

The simultaneous acquisition is seen evidently in the behaviour of doubling, but this behaviour is limited and applied only to a special case. The behaviour of multiplying is quite free from such a limitation. Accordingly the process of the multiplication is formed as follows;

a) to recognise each group as equal which is given as such and to treat it as 
an unit,

b) to count those units and to find the number of all groups,

c) to get the third number by the help of the multiplication-table to which two kinds of numbers are applied,

d) to understand this number, the product, as the total number of all elements of all groups that are given.

In this behaviqur, we can see, how great a part the multiplication-table plays. This table, to be sure, is created and constructed by an operator himself and never given from outside, though he is led by his teacher to systematize it logically and to make use of it generally.

(From the Psychological Institute, Hosei-University)

On the Threshold of Colour Expression

by

A. SASAME \& KIDO

The names of colour which we use in our daily life are so ambiguous that it is difficult to determine the limit of colour represented by a certain name in some manner. The 3549 thresholds of colour discrimination are found by Weissenborn, but we have not so many names that we. can express such a number of colour thresholds. Kirschmann adopts Rot, Orange, Gelb, Gelbgrün, Grün, Blaugrün, Grünblau, Violettblau, Violett, Purper, Purperrot as a terminology of colour, but colours with proper name are only seven and the others are expressed, as middle colours, by combining two names of colours. If a certain colour can be expressed in such a way, does it mean that we can perceive two colours at the same time? Such a terminology seems to fall into the stimulus error. A certain colour name would be applicable to wide limit of colourdiscrimination, because 3549 colours can be expressed by only 12 names of colours. Therefore we have to distinguish the threshold of colour expression from that of colourdiscrimination. The words express the thing in abstract rather in concrete, and consequently a colour in abstract. Our experiments intend to explain the relation of colour abstaction and colour constancy expressed in colour naming.

Exp. I. On the determination of threshold of colour expression

Instrument; Marbe's colour mixture. Method; Subjects observe the changing colour by the method of minimal change and express adequate name at the distinct point. Order of colour change; yellow $\rightarrow$ red $\rightarrow$ yellow. yellow $\rightarrow$ green $\rightarrow$ yellow: green $\rightarrow$ blue $\rightarrow$ green. blue $\rightarrow$ red $\rightarrow$ blue. Subjects; 5 adults and 5 children.

Results; 1) Threshold is larger in children than in adults except in the case 